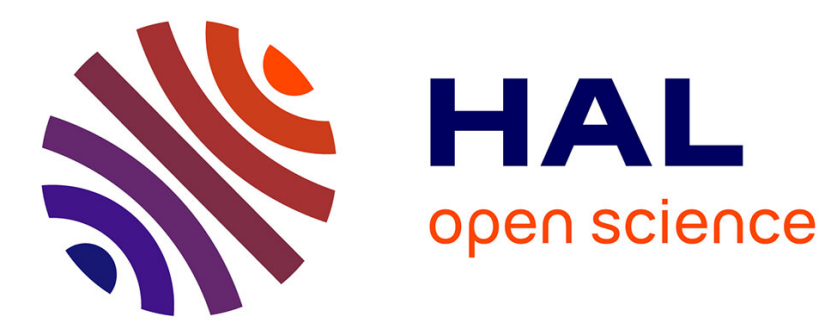

\title{
Biofuel Impact on Diesel Engine After-Treatment: Deactivation Mechanisms and Soot Reactivity
}

\author{
E. Iojoiu, V. Lauga, J. Abboud, G. Legros, J. Bonnety, P. da Costa, J.
} Schobing, A. Brillard, G. Leyssens, V. Tschamber, et al.

\section{- To cite this version:}

E. Iojoiu, V. Lauga, J. Abboud, G. Legros, J. Bonnety, et al.. Biofuel Impact on Diesel Engine AfterTreatment: Deactivation Mechanisms and Soot Reactivity. Emission Control Science and Technology, 2018, 4 (1), pp.15-32. 10.1007/s40825-017-0079-x . hal-03108563

\section{HAL Id: hal-03108563 \\ https://hal.science/hal-03108563}

Submitted on 13 Jan 2021

HAL is a multi-disciplinary open access archive for the deposit and dissemination of scientific research documents, whether they are published or not. The documents may come from teaching and research institutions in France or abroad, or from public or private research centers.
L'archive ouverte pluridisciplinaire HAL, est destinée au dépôt et à la diffusion de documents scientifiques de niveau recherche, publiés ou non, émanant des établissements d'enseignement et de recherche français ou étrangers, des laboratoires publics ou privés. 


\section{Biofuel impact on Diesel engine after-treatment: deactivation mechanisms and soot reactivity}

E. Iojoiu ${ }^{1}$, V. Lauga ${ }^{1}$, J. Abboud ${ }^{2}$, G. Legros ${ }^{2}$, J. Bonnety ${ }^{2}$, P. Da Costa ${ }^{2}$, J. Schobing ${ }^{3}$, A. Brillard ${ }^{3}$, G. Leyssens $^{3}$, V. Tschamber ${ }^{3}$, P. Anguita ${ }^{4}$, J.G. Vargas ${ }^{4}$, L. Retailleau ${ }^{4}$, S. Gil ${ }^{4}$, A. Giroir-Fendler ${ }^{4}$, M.-L. $\operatorname{Tarot}^{5}$, F. Can ${ }^{5 *}$, D. Duprez ${ }^{5}$, X. Courtois ${ }^{5 *}$

${ }^{1}$ Renault Trucks - Volvo Group Trucks Technology, Powertrain Engineering, 99 route de Lyon - 69806 Saint-Priest Cedex, France

${ }^{2}$ Sorbonne Universités, UPMC, Univ. Paris 6, CNRS, UMR 7190Institut Jean Le Rond d'Alembert (IJLRA), 2 place de la gare de ceinture, 78210 Saint-Cyr-L'Ecole, France,

${ }^{3}$ Université de Haute Alsace, Laboratoire Gestion des Risques et Environnement (LGRE) EA2334, 3b rue A. Werner, Institut J.B. Donnet, 68093 Mulhouse Cedex, France

${ }^{4}$ Université de Lyon, Lyon, F-69003, France, Université Claude Bernard Lyon 1, Villeurbanne, F69622, CNRS, UMR 5256, IRCELYON, 2 avenue Albert Einstein, Villeurbanne, F-69622, France

${ }^{5}$ Institut de Chimie des Milieux et des Matériaux de Poitiers (IC2MP), Université de Poitiers-CNRS, UMR 7285, 4 rue Michel Brunet, TSA 51106, 86073 Poitiers Cedex 9, France

*Corresponding authors $\quad$ xavier.courtois@univ-poitiers / tel: +33 549453994

fabien.can@univ-poitiers.fr / tel: +33 549453997

Keywords: BioDiesel, exhaust gas control, DOC, DPF, SCR, inorganic elements. 


\section{Abstract:}

Since 2014 (Euro VI), heavy goods vehicles must be equipped with a complex exhaust gas posttreatment system including a diesel oxidation catalyst (DOC), a catalyst for the selective reduction of $\mathrm{NO}_{\mathrm{x}}(\mathrm{SCR})$, and a diesel particulate filter (DPF), with a required durability of seven years or 700,000 $\mathrm{km}$. Consequently, when biodiesel is used, especially pure biodiesel (B100), catalysts will be subjected over 700,000 km to kilograms of inorganic elements ( $\mathrm{Na}, \mathrm{K}$, and P), even if they are limited to a few ppm in biodiesel fuel. The durability of the catalytic exhaust system is therefore questionable. This issue is of major concern to vehicle manufacturers.

This study aims to make a detailed investigation of the impact of biodiesel use on the durability of the existing Euro VI catalytic systems, with a special focus on deactivation through poisoning for DOC and SCR catalysts, and on the physics and chemistry of particles and their reactivity.

\section{Context and Challenges}

Emission standards for the pollutants in automobile exhaust are continually becoming stricter. On $1^{\text {st }}$ January 2014, the Euro VI standard for heavy goods vehicles came into effect. It aims to reduce $\mathrm{NO}_{\mathrm{x}}$ emissions by $80 \%$ and particle emissions by $66 \%$ compared to the previous Euro $\mathrm{V}$ standard. As a result, vehicle manufacturers must introduce a diesel particulate filter (DPF) in addition to the selective catalytic reduction system (SCR), which targets $\mathrm{NO}_{\mathrm{x}}$ emission through the use of urea, and to the diesel oxidation catalyst (DOC), which processes carbon monoxide (CO) and unburned hydrocarbons (HC).

A Euro VI exhaust line therefore represents complex, expensive technology that henceforth includes three complementary catalytic systems for dealing specifically with each type of pollutant. The durability required by the Euro VI standard, in keeping with the typical use of these vehicles, is equally severe, reaching seven years or 700,000 km.

In addition to these standards that limit polluting emissions, the European states have made commitments to reduce emissions of greenhouse gases, especially those of $\mathrm{CO}_{2}$. To this end, European Directive 2009/33/CE imposes increased use of biofuels. More recently a Directive published on $17^{\text {th }}$ October $2012(\operatorname{COM}(2012) 595)$ proposes to limit the volume of agriculture-based biofuels to 5\% until 2020, while maintaining the objective of $10 \%$ renewable fuels in the transport energy mix at this date.

Biodiesel presents calorific values just few percent lower than those of a traditional diesel fuel (typically $33 \mathrm{MJ} \mathrm{L}^{-1}$ vs $35 \mathrm{MJ} \mathrm{L}^{-1}$ ), which gives it a clear advantage with respect to bioethanol, for instance. Biodiesel thus remains a promising renewable fuel that can make it possible to limit the dependence on fossil fuels such as conventional diesel fuel emanating from oil, while limiting the carbon impact of vehicles. Nevertheless, its intensive use can prove detrimental with regard to catalytic post-treatment. In fact, biofuels are known to contain alkali metals $(\mathrm{Na}, \mathrm{K})$ or phosphorus $(\mathrm{P})$, which are potential poisons for the post-treatment chain. The European norm EN 14214 sets the maximum contents of 
alkalis and phosphorus at 5 and $4 \mathrm{ppm}$, respectively. These elements are present in the fuel due to the use of $\mathrm{NaOH}$ or $\mathrm{KOH}$ catalyst for the liquid-phase synthesis of biodiesel.

In addition, some captive fleets of buses or trucks, however, are fuelled exclusively by biodiesel (B100). In this situation, based on an average fuel consumption of $35 \mathrm{~L} / 100 \mathrm{~km}$ for a truck fuelled exclusively by biodiesel, the exhaust system can be subjected to approximately $1 \mathrm{~kg}$ of alkali metals and $1 \mathrm{~kg}$ of phosphorus over a distance of 700,000 km (for a fuel consumption of approximately $208,000 \mathrm{~kg}$ ). These quantities are considerable, leading to a genuine risk of not attaining the durability required for posttreatment catalytic converters, even with lower levels of alkalis and phosphorus. It should be noted that these inorganic elements are also found in lubricating oils (part of which makes its way into the exhaust) and in the urea aqueous solution (Adblue ${ }^{\circledR}$ ) used for the NOx treatment (to a maximum of $0.5 \mathrm{mg} / \mathrm{kg}$ for each metal [1]), which further increases the risk of poisoning. To date, the behaviour of the posttreatment chain under such working conditions remains rather poorly understood. This is a major concern for manufacturers, particularly with respect to the cost of the post-treatment system because it could be necessary to replace it one or several times over the lifetime of the vehicle, depending on use. The replacement cost of a Euro VI post-treatment system could exceed 5\% of the price of the new vehicle.

This multidisciplinary work aims to make a detailed study of the durability of the post-treatment system as a whole when biodiesel is used on a massive scale (DOC and SCR poisoning; reactivity of the distinctive soot formed, etc.) by taking into account the interdependence among the different posttreatment units.

\section{State of the Art}

Considerable efforts have been made over the last few years to understand the effects of ageing on the performance of diesel oxidation catalysts (DOC), $\mathrm{NO}_{\mathrm{x}}$ reduction systems and diesel particulate filters (DPF) [2-10], especially with respect to meeting the EURO VI/6 standards. Nevertheless, there is relatively little scientific data available that satisfactorily describe the effects of biofuels on this pollution control chain.

As for any new fuel considered, it is important to understand its potential impact on the functioning of each part of the vehicle. Combustion characteristics strongly vary with evaluation conditions but biodiesel combustion is generally comparable to that of a conventional diesel fuel [11-13]. However, it has been demonstrated that its use leads to modified emissions and alters emission control. For example, Wang et al. [14] have shown that adding oxygenated hydrocarbons (HC) to diesel can lead to an increase in $\mathrm{HC}, \mathrm{CO}, \mathrm{NO}_{\mathrm{x}}$ and $\mathrm{NO}_{2}$ emissions, but at the same time to a decrease in the number of particulate matters. On the other hand, the use of fatty acid methyl esters leads to a decrease in the size of particles formed, while their number is not significantly affected [15]. 
Other reports have clearly pointed out a significant increase in the emission of regulated pollutants (nitrogen oxides, particles) when B20 or B100 is used (Bxx means that the fuel contains $\mathrm{xx} \%$ of biodiesel). Emissions of $\mathrm{NO}_{\mathrm{x}}$ can increase by $35 \%$ when $\mathrm{B} 100$ is used exclusively [16,17]. A 60 to $80 \%$ increase in particles in the exhaust gases has also been reported for biodiesel use [17].

These few examples illustrate the fact that most of the available studies take a descriptive approach to the phenomena involved, by relating experimental conditions and overall results, but rarely describe the relationship between physico-chemical characteristics and reactivity. Finally, in terms of emissions and of impact on post-treatment systems, biodiesel use presents two specific features:

(i) It can lead to the emission of oxygenated molecules of varying reactivity. For example, compounds such as formaldehyde or butanone seem to be resistant to current oxidation catalysts $[18,19]$. Phenol or anisole [20] can be precursors for coke formation, especially on the catalysts used for $\mathrm{NO}_{\mathrm{x}}$ treatment [21]. Nonetheless, certain alcohols are also shown to be potential $\mathrm{NO}_{\mathrm{x}}$ reducers [22].

(ii) It subjects the post-treatment system to inorganic poisons that can modify the type and reactivity of soot.

Even though the impact of oxygenated $\mathrm{HC}\left(\mathrm{HC}_{\text {oxygenated }}\right)$ on the effectiveness of the pollution control system cannot be completely neglected, this work aims to make a detailed study of the durability of the overall post-treatment system in the case of extensive biodiesel use, by focusing on the effect of inorganic poisons $(\mathrm{Na}, \mathrm{K}$, and $\mathrm{P}$ ). The expected impact of these poisons on the three post-treatment systems (DOC, SCR, DPF) is described below.

\subsection{Diesel Oxidation Catalyst (DOC)}

The DOC is usually placed close to the engine and has to exhibit low-temperature oxidation activity and also excellent thermal stability because the DOC is regularly submitted to transient HC peaks to initiate the active DPF regeneration. DOCs are mainly composed of noble metals (platinum, palladium) deposited on stabilised alumina-based supports (lanthanide) and doped with mixed oxides of the ceriazirconia type (high oxygen mobility) and with zeolites. The role of the DOC is to facilitate the oxidation of unburned hydrocarbons and carbon monoxide through the use of oxygen, thereby producing $\mathrm{CO}_{2}$. This catalyst is also involved in the oxidation of $\mathrm{NO}$ into $\mathrm{NO}_{2}$. In turn, $\mathrm{NO}_{2}$ is involved both in the passive regeneration of the DPF and in the SCR reaction. A deactivation of the DOC can therefore have an impact on the post-treatment system as a whole.

Regarding the inorganic elements that result from biodiesel use, it has been demonstrated that alkali metals $(\mathrm{Na}, \mathrm{K})$ can strongly interact with alumina-based supports. In this way, these metals poison the unsaturated cationic sites. It has for example been established that one sodium atom poisons three Lewis acid sites of an alumina [23]. In addition, these alkali metals lead to the formation of basic oxides, which are known to generate a certain deactivation of precious metals such as platinum, particularly for 
oxidation reactions. Indeed, a basic oxide tends to maintain platinum in a more highly oxidised state. These basic oxides can nonetheless also present a certain $\mathrm{NO}_{\mathrm{x}}$ storage capacity.

Relatively little information is available regarding the potential role of phosphorus, even if phosphorus is reputed to be a sintering agent. At high temperatures $\left(700^{\circ} \mathrm{C}\right)$, phosphorus favours the growth of platinum particles and affects platinum structure [24,25]. Phosphorus also interacts with platinum by forming platinum phosphide [26]. Nevertheless, contrasted results are available and Matam et al. [27] reported in 2013 that phosphorus limits the extensive growth of platinum, by favouring spherical particles. Even though phosphorus considerably modifies the stability of platinum, its effects are therefore not yet perfectly clear. Also, only platinum is considered in these studies, and the impact of phosphorus on the other noble metals, palladium in particular, is not addressed. Compared to platinum, however, palladium is more sensitive to sulphur, which is an element closely related to phosphorus.

The role that phosphorus plays as a sintering agent has also been highlighted for certain oxides that are commonly found in post-treatment catalysts [24,25]. Phosphorus leads to the sintering of ceria $\left(\mathrm{CeO}_{2}\right)$, with the formation of cerium phosphate $\left(\mathrm{CePO}_{4}\right)$. The alumina support is also affected, with an enlargement of the grains and a formation of aluminium phosphate $\left(\mathrm{AlPO}_{4}\right)$. Phosphorus also affects the zeolite network by generating dealumination and a modification of the unburned hydrocarbon storage properties (HC trap).

As for the impact of the DOC on the two other catalytic units, it has been shown that biodiesel use can lead to a decrease in the $\mathrm{NO}_{2} / \mathrm{NO}_{\mathrm{x}}$ ratio, which directly affects the effectiveness of the SCR system placed upstream of the DOC, and can also lead to an increase in the $\mathrm{NO}_{\mathrm{x}}$ content as well as to a decrease in the regeneration capacity of the DPF $[28,29]$.

These examples therefore clearly demonstrate that the presence of inorganic elements originating from biodiesel can have a significant impact on DOC performance.

\section{$\underline{2.2 \mathrm{NO}_{x}}$ Reduction Catalyst (SCR)}

For heavy goods vehicles, the usual $\mathrm{NO}_{\mathrm{x}}$ treatment process is the selective catalytic reduction (SCR), performed continuously via Adblue ${ }^{\circledR}$ injection (Adblue ${ }^{\circledR}$ is an aqueous solution with $32.5 \mathrm{wt} \%$ urea, which is used as ammonia precursor). This process requires the use of solid acid catalysts (oxides or zeolites). In an oxidising environment (which is the case of diesel engines), several chemical reactions can occur depending in particular on the $\mathrm{NO} / \mathrm{NO}_{2}$ ratio, which strongly depends on the upstream DOC activity.

$2 \mathrm{NH}_{3}+2 \mathrm{NO}+1 / 2 \mathrm{O}_{2} \rightarrow 2 \mathrm{~N}_{2}+3 \mathrm{H}_{2} \mathrm{O} \quad$ Equation 1, referred to standard SCR

$2 \mathrm{NH}_{3}+\mathrm{NO}+\mathrm{NO}_{2} \rightarrow 2 \mathrm{~N}_{2}+3 \mathrm{H}_{2} \mathrm{O}$

Equation 2, referred to fast SCR

$4 \mathrm{NH}_{3}+3 \mathrm{NO}_{2} \rightarrow 7 / 2 \mathrm{~N}_{2}+6 \mathrm{H}_{2} \mathrm{O}$

Equation 3, referred to $\mathrm{NO}_{2} \mathrm{SCR}$

As its name suggests, reaction 2 is preferable. 
Over typical SCR catalysts, the SCR reaction by ammonia involves an initial step with adsorption of $\mathrm{NH}_{3}$ on the acid sites of the material, prior to reaction with $\mathrm{NO}$ or $\mathrm{NO}_{2}$ emanating from the gas phase (Eley-Rideal type mechanism) [30-35]. A key step governing the intrinsic activity of these materials therefore resides in the adsorption of $\mathrm{NH}_{3}$ on the Lewis or Brønsted acid sites of the catalyst. Consequently, alkali metals, which present a pronounced basic character, are expected to interact with the acid sites of the catalysts. The catalysts used for heavy goods vehicles up to Euro VI regulation was $\mathrm{V}_{2} \mathrm{O}_{5}-\mathrm{WO}_{3} / \mathrm{TiO}_{2}$-base acidic oxides [36,37]. As expected, it has been shown that these solids are deactivated in the presence of alkali metals. More specifically, with this type of material, Wan et al. [38] have established that deactivation effects occur in the following order: $\mathrm{K}>\mathrm{Na} \sim \mathrm{Ca}>\mathrm{Mg}$. Potassium has the strongest effect because it leads to the formation of potassium metavanadate $\left(\mathrm{KVO}_{3}\right)$, which selectively poisons vanadium. Other studies have reported a significant decrease in specific surface area [39], a modification in the valence state of vanadium [40] and a poisoning of the acid sites [41] of the catalyst when potassium is deposited. Finally, on titania- and zirconia-based oxide supports (whether sulphated or not), the addition of transition metals $(\mathrm{Fe}, \mathrm{Cu}$, etc.) appears to induce a Lewis-type acidity, which moderately reinforces the resistance of these materials to poisoning by alkali metals [42].

In addition, the Euro VI standard induces the addition of a DPF into the post-treatment chain of heavy goods vehicles and places new constraints on the SCR catalyst. Indeed, the thermal resistance of vanadium-based materials is incompatible with the exotherms induced by the active regeneration of a DPF. The deactivation of $\mathrm{V}_{2} \mathrm{O}_{5}$-based sample is mainly assigned to the anatase-rutile transition of $\mathrm{TiO}_{2}$ [43] and vanadia sublimation [44]. Consequently, new thermally stable SCR catalysts, based on exchanged zeolite with a transition metal such as copper or iron, have been designed [45-47]. Compared with iron exchanged zeolites, copper-zeolite catalysts were reported to be more active at low temperature $\left(<300^{\circ} \mathrm{C}\right.$ ), less sensitive to $\mathrm{NO}_{2} / \mathrm{NO}_{\mathrm{x}}$ ratio, but produced more $\mathrm{N}_{2} \mathrm{O}$ (a powerful greenhouse gas) [48]. With such very acidic catalysts, a strong interaction with basic alkali metals can be expected to occur. Without establishing which function(s) would be most affected ( $\mathrm{NH}_{3}$ storage, redox function, etc.), Brookhear et al. showed that a $\mathrm{Cu} /$ zeolite catalyst (BASF) is deactivated in the presence of sodium, especially within the DOC-SCR-DPF configuration and at low $\mathrm{NO}_{2}$ concentrations [49]. For a non-poisoned catalyst, the $\mathrm{NO}_{2}$ concentration has less impact, even though it is also known that the effectiveness of these zeolites is largely dependent on the $\mathrm{NO}_{2} / \mathrm{NO}_{\mathrm{x}}$ ratio. The latter being linked to the oxidation properties of the DOC, this is yet another illustration of a relationship among the deactivations of the different pollution control systems. 


\subsection{Diesel Particulate Filter (DPF)}

With respect to particulate emissions, it has been shown that biodiesel use can lead to a decrease in the temperature of soot combustion, with an increase in the organic fraction of the particulate matter [29,5053].

In 2012, a study has shown that the forced regeneration of a DPF is facilitated when synthetic diesel fuel is used, whereas passive regeneration is facilitated when biodiesel is used [54].

In another recent study involving a B20-type fuel (20\% biodiesel / 80\% conventional diesel), the presence of sodium was found to lead to higher ash contents in the particulate filter and thereby to affect its functionality and its performance capacity [49]. According to Salamanca et al. [55], the soot generated by biodiesels (B50 to B100) presents similar morphology to that produced upon combustion of usual fossil-based diesel. However, Vander Wal et al. [56] have shown by HRTEM studies that soot produced with biodiesel fuel are more amorphous and thus more reactive. It nonetheless presents a higher $\mathrm{C}$ content than does diesel soot, in addition to $\mathrm{K}, \mathrm{Ca}, \mathrm{Si}, \mathrm{Na}, \mathrm{Fe}, \mathrm{Mg}$ and $\mathrm{P}$ contents between 0.2 and $1 \%$. These inorganic elements, which are involved in ash formation in the DPF, are not detected in diesel soot. The impact of soot composition on combustion kinetics was not, however, considered in this study.

Finally, the state of the art clearly demonstrates the mostly negative effects of the use of diesel biofuels on the activity of each post-treatment system in the exhaust line. This research is nevertheless not fully developed. The studies mentioned have taken either a descriptive approach, essentially highlighting the general overall tendencies of the impact of biodiesels on emissions, or a piecemeal approach focusing on very specific studies (one poison associated with one system). Fundamental data at an intermediate scale are therefore lacking.

By adopting a primarily fundamental approach, this project seeks to bring to light the relationships between the physico-chemical properties of catalysts (fresh and poisoned) and those of soot, and the effectiveness of the post-treatment processes exposed to biodiesel use.

\section{Developed strategies for each depollution system and results}

\subsection{Diesel Oxidation Catalyst (DOC)}

This study aims to determine how the DOC catalyst is deactivated with regard to the presence of biodiesel components such as $\mathrm{Na}, \mathrm{K}$, and $\mathrm{P}$, with a special focus on the $\mathrm{NO}_{2}$ production involved in both SCR and DPF reactivity. The goal is to establish relationships between catalytic activity and poisoning, and possibly to determine a critical threshold for the poison contents. With a more detailed approach, another aim is to characterise the interactions among the poison(s) and the metallic and oxide phases (supports), in order to link them with the catalytic activity results. The objective is therefore to determine if these treatments have an additional detrimental effect or if they lead to a certain degree of regeneration. 
Once these various effects have been identified, it will be possible to suggest new catalyst formulations that are more resistant to these new fuels.

\subsubsection{Catalyst synthesis}

The reference DOC catalyst is based on high surface La-stabilised alumina doped with ceria-zirconia (to increase the oxygen storage) and with precious metals like platinum and/or palladium as the active phase for oxidation reactions.

$\gamma-\mathrm{Al}_{2} \mathrm{O}_{3}$ provided by Alfa Aesar was firstly calcined at $650^{\circ} \mathrm{C}$ for $5 \mathrm{~h}$ under wet air $\left(50 \mathrm{ml} \mathrm{min}^{-1}, 10 \%\right.$ water). Once alumina was calcined, $4 \mathrm{wt} \%$ of lanthanum was added by incipient wetness impregnation of an aqueous solution of $\mathrm{La}\left(\mathrm{NO}_{3}\right) \cdot 6 \mathrm{H}_{2} \mathrm{O}$. Thereafter, aqueous solution of $\mathrm{Ce}\left(\mathrm{NO}_{3}\right)_{3} \cdot 6 \mathrm{H}_{2} \mathrm{O}$ (Sigma Aldrich) and $\mathrm{ZrO}\left(\mathrm{NO}_{3}\right)_{2} \cdot \mathrm{xH}_{2} \mathrm{O}$ (Sigma Aldrich) was co-impregnated to the La-alumina support, developing a complementary phase with $10 \mathrm{wt} \%$ of ceria-zirconia.. Finally, platinum and palladium were added by incipient wetness impregnation of the $\mathrm{CeZr} / \mathrm{La}-\mathrm{Al}_{2} \mathrm{O}_{3}$ support, with $\mathrm{Pt}\left(\mathrm{NH}_{3}\right)_{4}\left(\mathrm{NO}_{3}\right)_{2}$ and $\mathrm{Pd}\left(\mathrm{NO}_{3}\right)_{2}$ as precursors (Sigma Aldrich). After each impregnation step (La, Ce-Zr, Pt-Pd), the resulting sample was dried at $100^{\circ} \mathrm{C}$ and hydrothermally treated at $650^{\circ} \mathrm{C}$ under same conditions as alumina support stabilisation. The obtained catalyst (denoted Pt-Pd, reference catalyst) was $1.2 \mathrm{wt} \%$ $\mathrm{PtPd} / \mathrm{CeZr} / \mathrm{La}-\mathrm{Al}_{2} \mathrm{O}_{3}$, with $\mathrm{Pt} / \mathrm{Pd}$ and $\mathrm{Ce} /(\mathrm{Ce}+\mathrm{Zr})$ wt ratio of 2 and 0.7 , respectively.

To simulate the behaviour of the catalyst after biodiesel use, alkali ( $\mathrm{Na}, \mathrm{K})$ and phosphorus were supplemented to the catalyst. These poisons were incorporated by the same method, incipient wetness impregnation of aqueous solutions of $\mathrm{NaNO}_{3}, \mathrm{KNO}_{3}$ or $\left(\mathrm{NH}_{4}\right)_{2} \mathrm{HPO}_{4}$ (Sigma Aldrich). The poisoned catalysts obtained were: $1.6 \mathrm{wt} \% \mathrm{Na}-\mathrm{PtPd} / \mathrm{CeZr} / \mathrm{La}-\mathrm{Al}_{2} \mathrm{O}_{3}, 0.5 \mathrm{wt} \% \mathrm{~K}-\mathrm{PtPd} / \mathrm{CeZr} / \mathrm{La}-\mathrm{Al}_{2} \mathrm{O}_{3}$ and $5.6 \mathrm{wt} \%$ $\mathrm{P}-\mathrm{PtPd} / \mathrm{CeZr} / \mathrm{La}-\mathrm{Al}_{2} \mathrm{O}_{3}$ (Table 1). Poisons amount was established to simulate the accumulation of biodiesel and oils impurities in the catalyst after long-term biodiesel employs.

\subsubsection{Catalyst activity tests and characterization technics}

Reference catalyst was evaluated both in its fresh state and after inorganic elements incorporation. The reactivity of the DOC was evaluated in complex mixtures simulating exhaust emissions containing 500 ppm NO, 300 ppm CO, 300 ppm C $_{3} \mathrm{H}_{6}, 5 \% \mathrm{CO}_{2}, 10 \% \mathrm{O}_{2}, 3.5 \% \mathrm{H}_{2} \mathrm{O}$ and $\mathrm{He}$ as carrier gas, with a total flow of $250 \mathrm{ml} \mathrm{min}^{-1}$. The water content was controlled by the vapour pressure of $\mathrm{H}_{2} \mathrm{O}$ using a heating bath to establish the saturator temperature $\left(28^{\circ} \mathrm{C}\right)$. The gas hourly space velocity (GHSV) of the total gas mixture was fixed at $135.000 \mathrm{~h}^{-1}$. Three consecutive catalytic cycles of $5^{\circ} \mathrm{C} \mathrm{min}^{-1}$ from $80^{\circ} \mathrm{C}$ up to $600^{\circ} \mathrm{C}$ were performed to analyse the catalytic activity and stability. All catalysts were tested during the heating ramp. To analyse the effluents gazes, a micro gas chromatograph (SRA \%GC-R3000), a flame ionization detector (FID-Agilent Technologies GC-FID 6850 Network GC) and an infrared-ultraviolet spectrometer (EMERSON IR/UV X-STREAM Enhanced XEGP) were used.

The amounts of noble metals, $\mathrm{Na}, \mathrm{K}$ or $\mathrm{P}$ were determined by inductively coupled plasma atomic emission spectroscopy (ICP-AES) on a flame Perkin Elmer M1100 spectrometer. Before the 
measurement, the metal oxides were dissolved using a mixture of inorganic acids $\left(\mathrm{H}_{2} \mathrm{SO}_{4}, \mathrm{HNO}_{3}\right.$ and HF).

Textural properties of the materials were studied using nitrogen physisorption. Nitrogen adsorption and desorption isotherms were measured at $-196^{\circ} \mathrm{C}$ on a Micromeritics ASAP 2020 surface area and porosity analyzer. Prior to the measurement, the catalysts were degassed at $300^{\circ} \mathrm{C}$ for $4 \mathrm{~h}$ under vacuum. The specific surface area of each catalyst was calculated from the linear part of Brunauer-Emmett- Teller $(\mathrm{BET})$ method $(\mathrm{P} / \mathrm{Po}=0.05-0.25)$.

\subsubsection{Results}

Noble metal and poisons loadings and physico-chemical properties of all catalysts are listed in Table 1. Chemical composition results showed that the incorporation of poisons had no influence on the amount of palladium. To the opposite, some elements as phosphorus or potassium decreased the platinum content.

Table 1. Physico-chemical properties and catalytic activity results of synthesized catalysts.

\begin{tabular}{cccccccc}
\hline Catalysts & \multicolumn{2}{c}{ Metal contents (wt\%) } & $\begin{array}{c}\text { Textural } \\
\text { parameters }\end{array}$ & $\begin{array}{c}\mathrm{r}_{\mathrm{NO}}{ }^{\mathrm{b}} \\
\left(\mathrm{mol} \mathrm{s}^{-1} \mathrm{~g}_{\mathrm{PGM}}{ }^{-1}\right)\end{array}$ & $\begin{array}{c}\mathrm{NO}_{2}{ }^{\mathrm{c}} \\
(\mathrm{ppm})\end{array}$ & $\begin{array}{c}\mathrm{N}_{2} \mathrm{O}^{\mathrm{c}} \\
(\mathrm{ppm})\end{array}$ \\
\cline { 2 - 5 } & $\mathrm{Pt}$ & $\mathrm{Pd}$ & Additive & $\mathrm{S}_{\mathrm{BET}}\left(\mathrm{m}^{2} \mathrm{~g}^{-1}\right)^{\mathrm{a}}$ & & & \\
\hline PtPd & 0.85 & 0.49 & - & 60 & 5.157 & 145 & 39 \\
$\mathrm{~K}-\mathrm{PtPd}$ & 0.56 & 0.48 & 0.5 & 57 & 2.048 & 118 & 46 \\
$\mathrm{Na}-\mathrm{PtPd}$ & 0.83 & 0.50 & 1.6 & 50 & 5.789 & 119 & 30 \\
P - PtPd & 0.64 & 0.46 & 5.6 & 33 & 4.268 & 127 & 25 \\
\hline
\end{tabular}

${ }^{\mathrm{a}} \mathrm{BET}$ specific surface area $\left(\mathrm{m}^{2} \mathrm{~g}^{-1}\right)$.

${ }^{b}$ Reaction rate ( $\mathrm{mol} \mathrm{s}^{-1} \mathrm{~g}_{\mathrm{PGM}}{ }^{-1}$ ) during the heating ramp at $250^{\circ} \mathrm{C}$ for $\mathrm{NO}$, during the first catalytic cycle. ${ }^{\mathrm{c}}$ Maximum concentration (ppm) of $\mathrm{NO}_{2}$ and $\mathrm{N}_{2} \mathrm{O}$ for each catalyst during the first heating ramp.

BET specific surface areas of alkali-poisoned catalysts were similar to the obtained with fresh reference catalyst. However, phosphorus addition produced a decrease in the specific surface area probably due to the pore blocking associated to phosphates formation [57]. The $\mathrm{N}_{2}$ adsorption/desorption isotherms of fresh and poisoned catalysts (not shown) exhibited a type IV isotherm typical of mesoporous materials based upon the Brunauer-Deming-Deming-Teller (BDDT) classification [58].

Catalytic oxidation activities were thereafter evaluated. Propene and carbon monoxide light-off temperatures (not shown) were similar for all catalysts with a full oxidation obtained around $200^{\circ} \mathrm{C}$ for both $\mathrm{CO}$ and $\mathrm{C}_{3} \mathrm{H}_{6}$. In contrast, $\mathrm{NO}$ conversion achieved maximum values of $60 \%$ at $350^{\circ} \mathrm{C}$ for the fresh reference catalyst and then decreased at higher temperatures due to thermodynamic limitations [59]. This maximum NO conversion decreased in presence of $\mathrm{Na}, \mathrm{K}$ and $\mathrm{P}$. The higher deactivation was denoted for $\mathrm{P}$ compounds, with the following poisoning order: $\mathrm{P}-\mathrm{PtPd} / \mathrm{CeZr} / \mathrm{La}-\mathrm{Al}_{2} \mathrm{O}_{3}>\mathrm{Na}-$ $\mathrm{PtPd} / \mathrm{CeZr} / \mathrm{La}-\mathrm{Al}_{2} \mathrm{O}_{3}>\mathrm{K}-\mathrm{PtPd} / \mathrm{CeZr} / \mathrm{La}-\mathrm{Al}_{2} \mathrm{O}_{3}>\mathrm{PtPd} / \mathrm{CeZr} / \mathrm{La}-\mathrm{Al}_{2} \mathrm{O}_{3}$. However, it is necessary to specify that the amount of added phosphorus was significantly higher to that of $\mathrm{Na}$ and especially $\mathrm{K}$, 
which may explain its higher influence on NO catalytic activity. To better understand this behaviour, the reaction rate of $\mathrm{NO}$ was calculated at $250^{\circ} \mathrm{C}$ ( $\mathrm{NO}$ conversion lower than $\left.10 \%\right)$, as converted mol by second and platinum and palladium mass (Table 1). It appears that no influence on the reaction rate was denoted after $\mathrm{Na}$ deposits. On the contrary, when potassium was supplemented, the reaction rate divided by more than 2. Moreover, Figure 1 reports $\mathrm{NO}_{2}$ and $\mathrm{N}_{2} \mathrm{O}$ selectivity versus temperature for all catalysts.
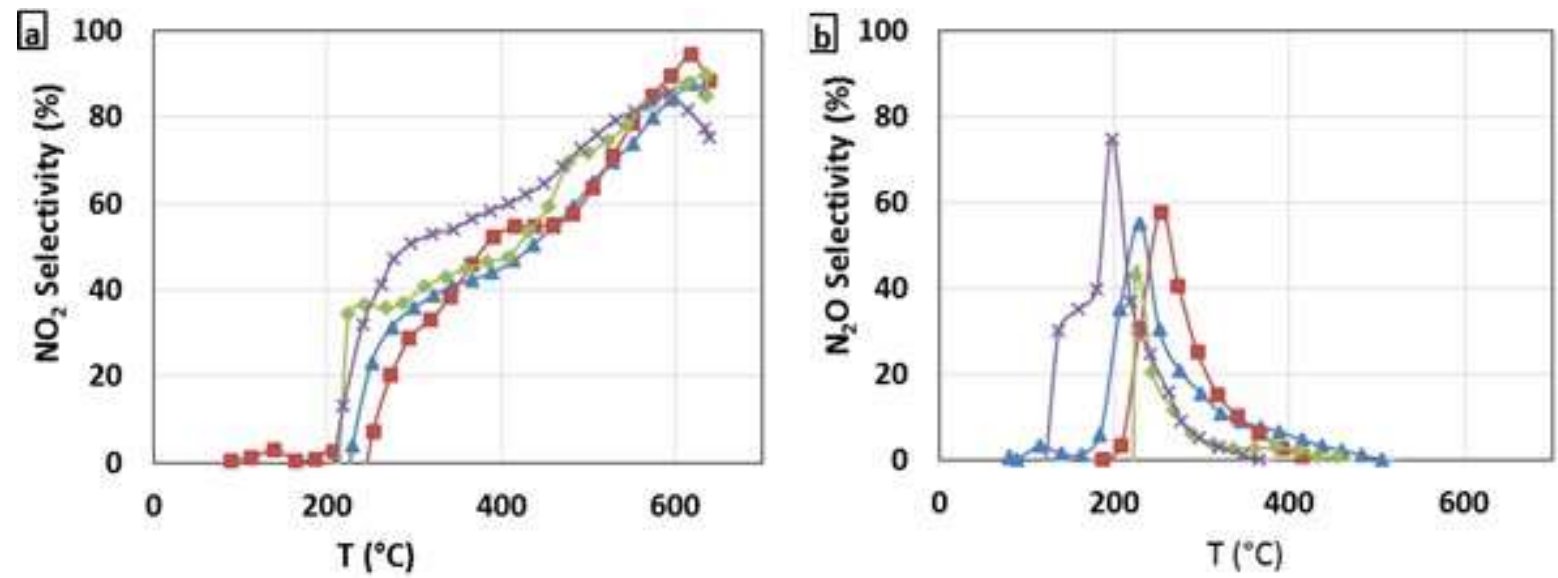

Fig. 1 a) $\mathrm{NO}_{2}$ and b) $\mathrm{N}_{2} \mathrm{O}$ selectivity versus temperature results obtained for fresh and modified reference DOC catalysts. $(\diamond)$ : PtPd; $(\square)$ : Na-PtPd; $(\boldsymbol{\Delta})$ : K-PtPd; (x): P-PtPd.

$\mathrm{NO}_{2}$ selectivity curves present the same shape for all catalysts, achieving its maximum value around $600^{\circ} \mathrm{C}$ and decreasing after this temperature. However, as reported in Table 1, a negative influence on $\mathrm{NO}_{2}$ production was observed in the presence of $\mathrm{Na}, \mathrm{K}$, and $\mathrm{P}$. Indeed, $\mathrm{Na}$ and $\mathrm{K}$ had a higher influence, decreasing $\mathrm{NO}_{2}$ formation from $145 \mathrm{ppm}$ until around $118 \mathrm{ppm}$, while phosphorus had also a negative influence, but less marked. Otherwise, selectivity to $\mathrm{N}_{2} \mathrm{O}$ presented its maximum value around $200^{\circ} \mathrm{C}$, coinciding with the temperature at which propene conversion was maximal. It is assumed that $\mathrm{N}_{2} \mathrm{O}$ production arises from $\mathrm{NO}$ reduction via $\mathrm{C}_{3} \mathrm{H}_{6}$-SCR. Consequently, $\mathrm{N}_{2} \mathrm{O}$ yield is concomitant with $\mathrm{C}_{3} \mathrm{H}_{6}$ oxidation. Comparing all studied catalysts, P-PtPd is the most selective to $\mathrm{N}_{2} \mathrm{O}$, although the maximum $\mathrm{N}_{2} \mathrm{O}$ concentration was observed in presence of $\mathrm{K}$, which was higher than the amount produced with the fresh reference catalyst.

In conclusion, the presence of $\mathrm{Na}, \mathrm{K}$ and $\mathrm{P}$ reduces $\mathrm{NO}_{2}$ production, especially when alkali compounds were supplemented to the catalysts. They can be considered as a poison for this reaction. This effect will have a negative influence in the effectiveness of DPF, as $\mathrm{NO}_{2}$ is used as an oxidant in passive regeneration of the filter; moreover, lower amount of $\mathrm{NO}_{2}$ will reduce the efficiency of fast SCR reaction. This point is thereafter illustrated in section 2.2.4. (Fig. 8).

\section{2. $\mathrm{NO}_{x}$ Reduction Catalyst (SCR)}

A methodology comparable to that previously described for the DOC was applied to the SCR catalysts. For this system, only the impact of the inorganic elements (content and type) was examined, while the HC 
content arriving on the SCR catalyst (post-DOC) was considered to be negligible. In accordance with the development a new generations of SCR catalysts based on metal exchanged small pore zeolites [60-64], the considered catalyst in this study is a copper exchanged ferrierite (FER). With such acidic materials, the presence of basic alkali metals is expected to lead to a poisoning of the acidic functional groups, and likely therefore to a decrease in the effectiveness of the deNO ${ }_{x}$ efficiency. Nevertheless, information concerning the deactivation of the redox sites of these materials appears lacking. The aim is then to establish relationships among physico-chemical characteristics, poisoning, and catalytic activity.

\subsubsection{Involved SCR catalysts: $\mathrm{Cu} / \mathrm{FER}$}

Ferrierite $\left(400 \mathrm{~m}^{2} \mathrm{~g}^{-1}\right)$ was chose as host zeolite structure and provided by Alfa Aesar. $\mathrm{The} \mathrm{SiO}_{2} / \mathrm{Al}_{2} \mathrm{O}_{3}$ ratio is equal to 20 . Copper (6.1 to $8.0 \%$ w ) was added by the ion-exchange technic. Copper nitrate salt was dissolved into water and the ion exchange was performed at $80^{\circ} \mathrm{C}$ for $23 \mathrm{~h}$. After drying, the powder was treated at $600^{\circ} \mathrm{C}$ under $10 \% \mathrm{O}_{2}-90 \% \mathrm{~N}_{2}$ for $30 \mathrm{~min}$ (heating rate: $2^{\circ} \mathrm{C} \mathrm{min}^{-1}$ ) and vapour water $(10 \%$ ) was then added for $30 \mathrm{~min}$ at $600^{\circ} \mathrm{C}$ before cooling to room temperature. Factually, three different batches were done for each considered inorganic element addition: $\mathrm{Na}, \mathrm{P}$ and $\mathrm{Na}+\mathrm{P}$ simultaneously. All the prepared catalysts contained exchanged copper and $\mathrm{CuO}$ particles in order to study the influence of the inorganic elements from biodiesel on the catalyst behaviours They all exhibited BET specific surface areas of approximately $350 \mathrm{~m}^{2} \mathrm{~g}^{-1}$ after the hydrothermal treatment at $600^{\circ} \mathrm{C}$.

Sodium $\left(\mathrm{NaNO}_{3}\right)$ or phosphorus $\left(\left(\mathrm{NH}_{4}\right)_{2} \mathrm{HPO}_{4}\right)$, or sodium and phosphorus simultaneously $\left(\mathrm{H}_{2} \mathrm{NaPO}_{4}\right)$, were added by impregnation in water. Finally, all the samples, with or without poisons, were submitted again to the thermal treatment composed of $30 \mathrm{~min}$ at $600^{\circ} \mathrm{C}$ under $10 \% \mathrm{O}_{2}-90 \% \mathrm{~N}_{2}$ and $16 \mathrm{~h}$ at $600^{\circ} \mathrm{C}$ under $10 \%$ $\mathrm{O}_{2}, 10 \% \mathrm{H}_{2} \mathrm{O}$ and $\mathrm{N}_{2}$. The effective $\mathrm{Cu}, \mathrm{Na}$ and $\mathrm{P}$ contents were measured by ICP and reported in Table 2 .

Table 2. Composition of the different SCR catalysts.

\begin{tabular}{cccc}
\hline $\begin{array}{c}\mathrm{Cu} \\
\left(\%_{\mathrm{w}}\right)\end{array}$ & $\begin{array}{c}\mathrm{Na} \\
\left(\%_{\mathrm{w}}\right) /\left(\mu \mathrm{mol} . \mathrm{g}^{-1}\right)\end{array}$ & $\begin{array}{c}\mathrm{P} \\
\left(\%_{\mathrm{w}}\right) /\left(\mu \mathrm{mol} . \mathrm{g}^{-1}\right)\end{array}$ & $\begin{array}{c}\mathrm{Na}+\mathrm{P} \\
\left(\mu \mathrm{mol.g} \mathrm{g}^{-1}\right)\end{array}$ \\
\hline \multirow{3}{*}{6.1} & 0 & 0 & - \\
& $1.2 / 515$ & 0 & - \\
\hline & $2.0 / 885$ & 0 & - \\
\hline \multirow{3}{*}{7.4} & 0 & 0 & - \\
& 0 & $1.4 / 465$ & - \\
\hline \multirow{3}{*}{8.0} & 0 & $2.8 / 915$ & 0 \\
& 0 & 0 & 420 \\
& $0.5 / 210$ & $0.6 / 210$ & 750 \\
\hline
\end{tabular}

\subsubsection{Catalytic tests}

The study of the impact of inorganic pollutants on the $\mathrm{NO}_{\mathrm{x}}$ reduction process in an oxidising environment (SCR) was performed under the realistic operating conditions described in Table 3. Even though in the targeted application the reducing agent is injected as an aqueous urea solution (Adblue ${ }^{\circledR}$ ), 
ammonia was used for its ease of implementation at the laboratory scale. Note that the effectiveness of the SCR catalysts is expected to be heavily influenced by the $\mathrm{NO}_{2} / \mathrm{NO}_{\mathrm{x}}$ ratio, which in turn depends on the oxidation properties of the DOC. However, in this study, mainly the unfavourable standard-SCR condition with $\left(\mathrm{NO} / \mathrm{NO}_{2}\right)_{\text {inlet ratio }}=1$ was examined.

Factually, $\mathrm{O}_{2}$ may compete with $\mathrm{NO}_{x}$ to react with $\mathrm{NH}_{3}$. Then, the catalyst behaviour toward the ammonia oxidation by $\mathrm{O}_{2}$ was also specifically examined (Table 3).

Table 3. Catalytic test set-up for SCR and ammonia oxidation experiments

\begin{tabular}{cccccccccc}
\hline Test & $\begin{array}{c}\text { Temp. } \\
\left({ }^{\circ} \mathrm{C}\right)\end{array}$ & $\begin{array}{c}\mathrm{NO} \\
(\mathrm{ppm})\end{array}$ & $\begin{array}{c}\mathrm{NO}_{2} \\
(\mathrm{ppm})\end{array}$ & $\begin{array}{c}\mathrm{NH}_{3} \\
(\mathrm{ppm})\end{array}$ & $\begin{array}{c}\mathrm{H}_{2} \mathrm{O} \\
(\%)\end{array}$ & $\begin{array}{c}\mathrm{CO}_{2} \\
(\%)\end{array}$ & $\begin{array}{c}\mathrm{O}_{2} \\
(\%)\end{array}$ & $\mathrm{N}_{2}$ & $\begin{array}{c}\text { Total flow } \\
\text { rate } \\
\left(\mathrm{mL}^{-m^{-1}}\right)\end{array}$ \\
\hline $\begin{array}{c}\text { Standard-SCR } \\
\mathrm{m}=50 \mathrm{mg}\end{array}$ & $200-500$ & 500 & & 500 & 9 & 10 & 10 & bal. & 250 \\
\hline $\begin{array}{c}\mathrm{NH}_{3} \text { oxidation } \\
\mathrm{m}=50 \mathrm{mg}\end{array}$ & $300-500$ & & & 500 & 9 & 10 & 10 & bal. & 250 \\
\hline
\end{tabular}

For all catalytic tests, the composition of the feed gas and effluent stream were analysed online with a MKS 2030 Multigas infrared analyser. A special focus was also placed on reduction selectivity, notably with respect to $\mathrm{N}_{2} \mathrm{O}$. However, $\mathrm{N}_{2} \mathrm{O}$ was never recorded in significant concentrations during the performed catalytic tests (maximum of $5 \mathrm{ppm}$, recorded at $500^{\circ} \mathrm{C}$ in Standard-SCR condition).

\subsubsection{Characterisation technics}

The SCR catalysts were characterised in order to establish relationships between activity and physicochemical characteristics, especially depending on the additions of the inorganic elements.

The $\mathrm{NH}_{3}$-SCR process involves acidic sites $[65,66]$. Then, the adsorption of basic probe molecules monitored by infrared is a technique of choice for evaluating the surface sites of a bulk solid. Qualitative and quantitative analysis of the acidic surface properties of the catalysts was performed via the adsorption/desorption of $\mathrm{NH}_{3}$ (pyridine is a too large molecule to enter in the small pores of the host zeolite $[67,68]$. Note that ammonia may also interact with copper species. Consequently, ammonias adsorption capacity may be not related only to acidic sites.

In order to assess to the copper state, Temperature Program Reduction (TPR) experiments were performed under $1 \% \mathrm{H}_{2}$ after in-situ calcination at $500^{\circ} \mathrm{C}$. The copper state was also examined by NO adsorption experiments followed by FTIR spectroscopy.

\subsubsection{Results}

$\mathrm{NO}_{\mathrm{x}}$ conversion curves of the $\mathrm{Cu}$-exchanged catalysts $(\mathrm{Cu}(6.1 \%) / \mathrm{FER}, \mathrm{Cu}(7.4 \%) / \mathrm{FER}$ and $\mathrm{Cu}(8.0 \%) / \mathrm{FER})$ exhibited the same profiles, with first an increase in the conversion with temperature and then a decrease at higher temperature, usually for $\mathrm{T}>350-400^{\circ} \mathrm{C} . \mathrm{NO}_{\mathrm{x}}$ and $\mathrm{NH}_{3}$ conversions were similar in the "low temperature" range, respecting the stoichiometry of the standard and fast SCR 
reactions. In opposition with the $\mathrm{NO}_{\mathrm{x}}$ conversion, the $\mathrm{NH}_{3}$ conversion continuously increased with temperature, until reaching $100 \%$. It illustrates the competition between SCR reaction and ammonia oxidation for $\mathrm{T}>350-400^{\circ} \mathrm{C}$.

Typical $\mathrm{NO}_{\mathrm{x}}$ and $\mathrm{NH}_{3}$ conversion curve of Cu-exchanged Ferrierite catalysts are reported in Figure 2, with or without sodium addition. In order to highlight the influence of the inorganics loading on the SCR catalytic activity, two representative temperatures were selected: $250^{\circ} \mathrm{C}$ and $500^{\circ} \mathrm{C}$. Figure $3 \mathrm{~A}$ and $\mathrm{B}$ reports the $\mathrm{NO}_{\mathrm{x}}$ conversion at these two selected temperature depending on the loading in inorganic elements, sodium, phosphorus and both with equimolar ratio.

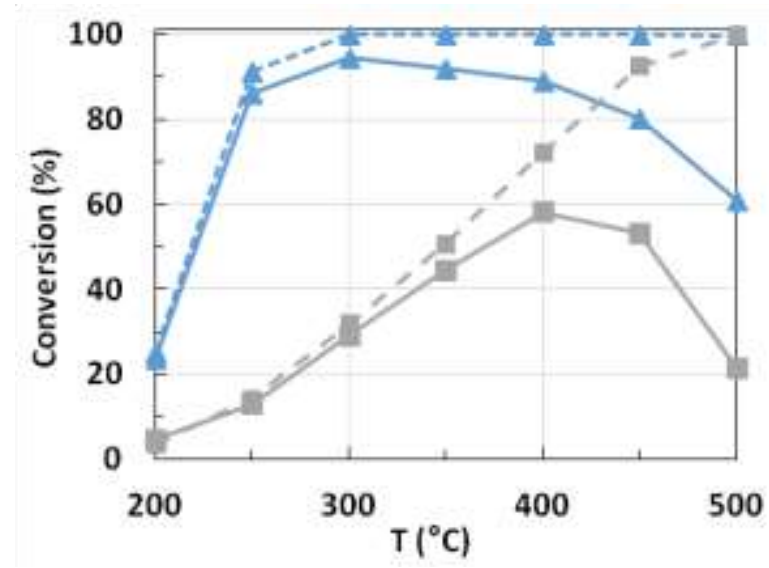

Fig. 2 Effect of sodium addition on $\mathrm{NO}_{\mathrm{x}}$ conversion (full lines) and $\mathrm{NH}_{3}$ conversion (dotted lines) over $\mathrm{Cu}(6.1 \%) / F E R$. ( $\Delta)$ : Na free sample; ( $\square$ ): Na poisoned $\left(885 \mu \mathrm{mol} \mathrm{g}{ }^{-1}\right)$ sample.

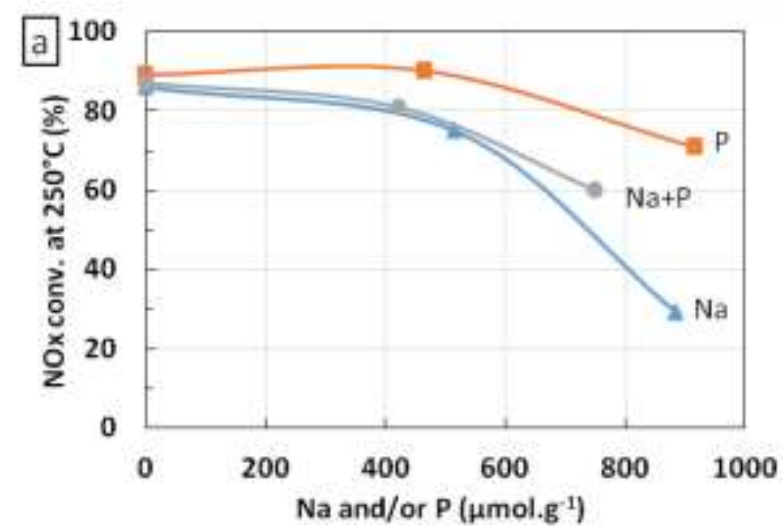

Fig. $3 \mathrm{NO}_{\mathrm{x}}$ conversion in standard-SCR at $250^{\circ} \mathrm{C}$

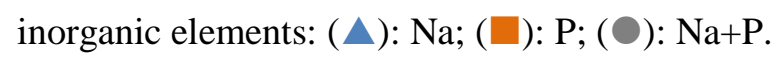

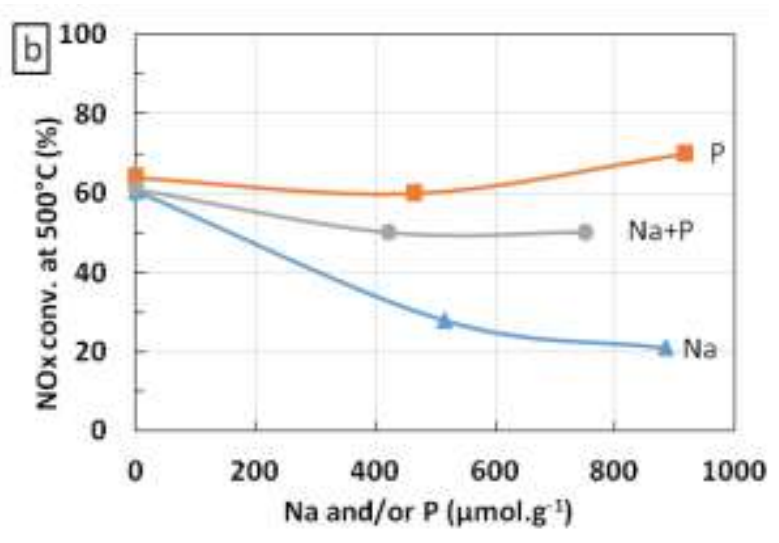

(a) and $500^{\circ} \mathrm{C}$ (b) depending on the loading in

At $250^{\circ} \mathrm{C}$, until $600 \mu \mathrm{mol} . \mathrm{g}^{-1}$ of poison content, the activity remained rather stable, with only a slight decrease for samples containing sodium, whereas phosphorus addition led to a small improvement of the $\mathrm{NO}_{\mathrm{x}}$ conversion. Consequently, the gap between samples was close to $10 \%$. For higher poison content, the activity dramatically dropped for sodium and sodium + phosphorus deposit, while the 
catalyst with only phosphorus was less affected. The $\mathrm{NO}_{\mathrm{x}}$ conversion then varied between $29 \%$ and 71 $\%$. Interestingly, Figure $3 \mathrm{a}$ shows that the $\mathrm{NO}_{\mathrm{x}}$ conversion for $\mathrm{Na}+\mathrm{P}$ poisoned catalyst mainly dependent of the Na loading.

At $500^{\circ} \mathrm{C}$ (Figure $3 \mathrm{~b}$ ), trends are different. The sodium poisoning still led to a significant drop of the $\mathrm{NO}_{\mathrm{x}}$ conversion rate, from approximately $60 \%$ to $20 \%$. On the contrary, addition of phosphorus allowed an improvement of the $\mathrm{NO}_{x}$ conversion for high $\mathrm{P}$ loading. The same result was observed on a Cu-SSZ13 [69], and it was attributed to an inhibition of the $\mathrm{NH}_{3}$ oxidation at high temperature. Consequently, ammonia was available in a higher extent for $\mathrm{NO}_{\mathrm{x}}$ reduction. At $500^{\circ} \mathrm{C}$, the catalyst containing both sodium and phosphorus exhibited an intermediate conversion between the sample with only sodium and the sample with only phosphorus. However, it seems that the contribution of phosphorus was predominant compared with the sodium one.

In order to investigate specifically the $\mathrm{NH}_{3}$ oxidation behaviour, additional tests were performed with the reaction mixture reported in Table 3. Results recorded at $400^{\circ} \mathrm{C}$ are reported in Figure 4.

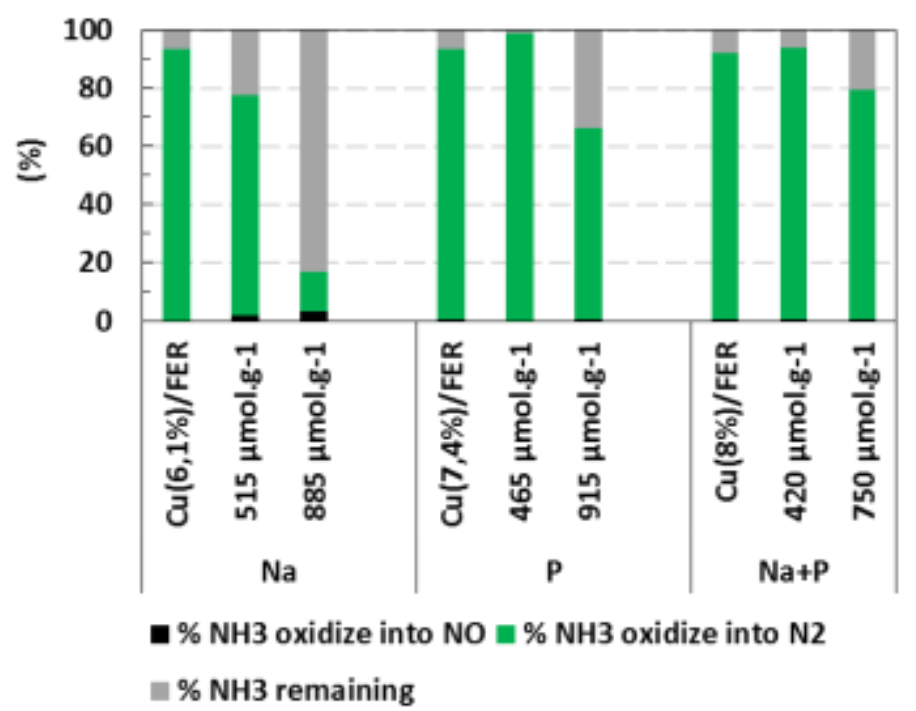

Fig. 4 Effect of $\mathrm{Na}, \mathrm{P}$ and $\mathrm{Na}+\mathrm{P}$ loading on $\mathrm{NH}_{3}$ oxidation activities at $400^{\circ} \mathrm{C}$

Before addition of inorganic elements, a high ammonia oxidation rate was achieved at $400^{\circ} \mathrm{C}(>90 \%)$, with a full selectivity into $\mathrm{N}_{2}$ for all catalysts (neither $\mathrm{NO}, \mathrm{NO}_{2}$ nor $\mathrm{N}_{2} \mathrm{O}$ were recorded). This result points out the ability of the catalyst for ammonia oxidation which was previously mentioned to explain the drop in $\mathrm{NO}_{\mathrm{x}}$ conversion at high temperature during the SCR tests (Figure 2).

After sodium impregnation, the ammonia oxidation strongly decreased and some traces of NO were recorded. Note that $\mathrm{NH}_{3}$ oxidation into $\mathrm{NO}_{2}$ was not observed.

With phosphorus addition, $\mathrm{NH}_{3}$ oxidation was improved with the intermediate loading (465 $\mu$ molp $\mathrm{g}^{-1}$ ) and then decreased for $915 \mu$ mol $_{\mathrm{P}} \mathrm{g}^{-1}$. However, the ammonia conversion remained higher than that observed after $\mathrm{Na}$ addition with similar content. No oxidized compounds such as NO were observed. 
When both inorganic elements were added $(\mathrm{Na}+\mathrm{P})$, the catalyst behaviour mainly depended on the phosphorus impact and the negative influence of $\mathrm{Na}$ was then counterbalanced by the phosphorus presence. Indeed, the catalyst modified by $750 \mu \operatorname{mol}_{(\mathrm{Na}+\mathrm{P})} \mathrm{g}^{-1}$ actually contained $375 \mu \mathrm{mol} \mathrm{g}^{-1}$ of each considered inorganic element, with a negative and positive impact for $\mathrm{Na}$ and $\mathrm{P}$, respectively.

Compared with SCR experiments, the decrease in the ammonia oxidation behaviour after Na addition did not lead to an increase in $\mathrm{NH}_{3}$-SCR efficiency. To the opposite, phosphorus deposits led to a decrease in ammonia oxidation together with an increase of the NOx conversion in $\mathrm{NH}_{3}-\mathrm{SCR}$. Regarding the results of the poisoning by $\mathrm{Na}+\mathrm{P}$, ammonia oxidation and standard-SCR at $500^{\circ} \mathrm{C}$ behaviours appeared dependant on the poisoning by $\mathrm{P}$, whereas the $\mathrm{NO}_{\mathrm{x}} \mathrm{SCR}$ à $250^{\circ} \mathrm{C}$ appeared mostly dependant on the sodium loading.

Finally, based on ammonia oxidation and SCR behaviours, it appears that Na and P interfere differently with the catalyst. As a result, $\mathrm{Na}$ or $\mathrm{P}$ deposits probably disturb different active sites.

To gain a better understanding of the changes in the catalytic behaviours, samples were characterized by $\mathrm{H}_{2}$-TPR to access to the copper state distribution. Reduction temperatures of the different copper species strongly depend on the zeolite structure and the $\mathrm{H}_{2}$-TPR set-up. However, in our experimental condition, the following attribution have been properly validated: for exchanged copper, two reduction peaks are expected, corresponding to the reduction of $\mathrm{Cu}^{\mathrm{II}}$ to $\mathrm{Cu}^{\mathrm{I}}\left(\approx 330^{\circ} \mathrm{C}\right)$ and the reduction of $\mathrm{Cu}^{\mathrm{I}}$ to $\mathrm{Cu}^{0}\left(\approx 950^{\circ} \mathrm{C}\right)$. If there is extra-framework copper, there is a direct reduction of $\mathrm{CuO}$ to $\mathrm{Cu}^{0}\left(250-350^{\circ} \mathrm{C}\right)$. Because of the dealumination of the zeolite, aluminate copper can also be formed, leading to a reduction peak in the $450-550^{\circ} \mathrm{C}$ temperature range. TPR profiles of the studied samples are presented in Figure 5.
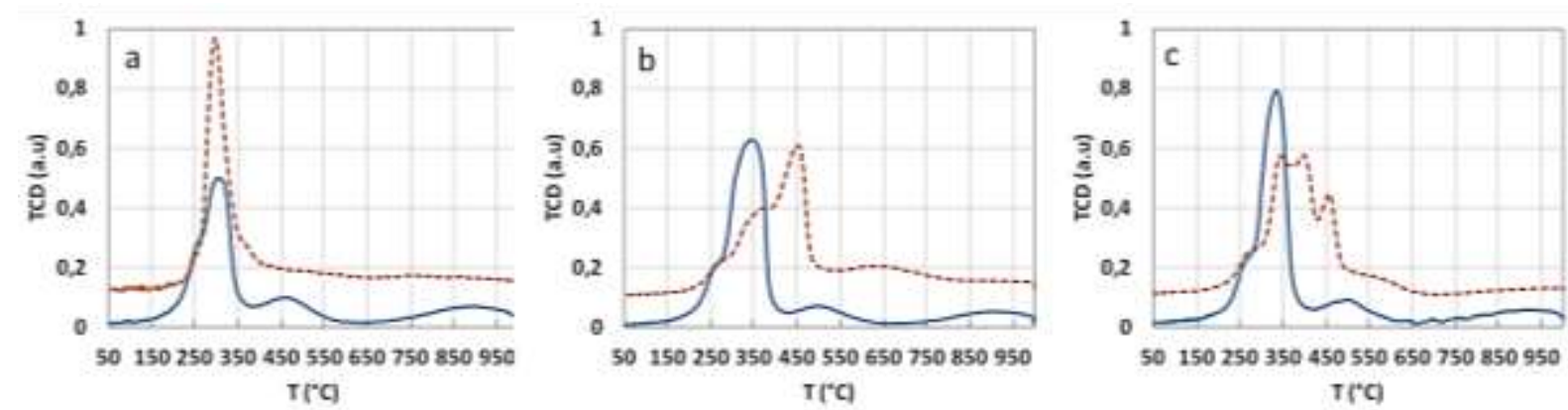

Fig. 5 Effect of the inorganic elements loading on $\mathrm{H}_{2}$-TPR profiles of $\mathrm{Cu}$ exchanged zeolite samples. a) $\mathrm{Cu}(6,1 \%) / \mathrm{FER}$ (full line); + $885 \mu \mathrm{mol} \mathrm{g}{ }^{-1} \mathrm{Na}$ (dotted line). b) $\mathrm{Cu}(7,4 \%) / \mathrm{FER}$ (full line); $+915 \mu \mathrm{mol} \mathrm{g}^{-1}$ $\mathrm{P}$ (dotted line). c) $\mathrm{Cu}(8 \%) / \mathrm{FER}$ (full line); $+750 \mu \mathrm{mol} \mathrm{g}{ }^{-1} \mathrm{Na}+\mathrm{P}$ (dotted line)

The three $\mathrm{Cu} / \mathrm{FER}$ samples all exhibit similar profiles before poisoning (blue curves). The first reduction peak is associated with $\mathrm{Cu}^{2+}$ exchanged copper reduction (into $\mathrm{Cu}^{+}$) and to $\mathrm{CuO}$ reduction. Copper 
aluminate reduction was then observed with a maximum near $450-550^{\circ} \mathrm{C}$. The broad reduction peak at high temperature correspond to $\mathrm{Cu}^{+}$reduction. For all sample, taking into account the copper loadings, the total $\mathrm{H}_{2}$ consumptions strictly corresponded to the reduction of all $\mathrm{Cu}^{\mathrm{II}}$ species into metallic $\mathrm{Cu}$.

After sodium poisoning (Figure 5a), a strong decrease in the amount of exchanged copper was observed (absence of the reduction peak at $950^{\circ} \mathrm{C}$, assigned to the second reduction step of exchanged $\mathrm{Cu}^{\mathrm{II}}$ ), in favour of $\mathrm{CuO}$ (no change in the total $\mathrm{H}_{2}$ consumption). The increase in $\mathrm{CuO}$ amount induce a decrease in accessible copper which is in accordance with the decrease in the ammonia oxidation activity reported in Figure 4.

After phosphorus addition, (Figure 5b), the amount of exchange copper also decreased. Moreover, a shift of the reduction peaks to higher temperatures is also observed, pointing out a direct interaction between copper and phosphorus. Note that similar shift to higher temperature was observed for copper deposit on silica when phosphorus was added. More precisely, Sepúlveda et al observed a decrease in the $\mathrm{CuO}$ reduction peak intensity with the appearance of a new peak at higher temperature assigned to copper phosphate or copper in interaction with phosphorus [70.71]. Note that for low P loading, the TPR profile (not shown) exhibited a small reduction peak around $250^{\circ} \mathrm{C}$, which then disappeared with the increase in the phosphorus content. These changes in copper reducibility can explain the observed evolution in ammonia oxidation. This influence of phosphorus addition was also noticed for $\mathrm{Na}+\mathrm{P}$ poisoning, with a decrease in the exchanged copper and a shift of the reduction temperatures to higher temperature.

The copper state was also investigated by NO adsorption monitored by FT-IR. Two main bands can be observed: one band at $1905-1910 \mathrm{~cm}^{-1}$ assigned to $\mathrm{Cu}^{\mathrm{II}}-\mathrm{NO}$ and the second at $1810 \mathrm{~cm}^{-1}$ assigned to $\mathrm{Cu}^{\mathrm{I}}$ NO [72]. Results reported in Figure 6 shows spectra corresponding to the NO adsorption on catalysts without any poison and the catalysts with the highest amount of inorganic elements. For each sample, the presence of $\mathrm{Cu}^{\mathrm{II}}-\mathrm{NO}$ and $\mathrm{Cu}^{\mathrm{I}}-\mathrm{NO}$ was noticed. The presence of $\mathrm{Cu}^{\mathrm{I}}-\mathrm{NO}$ was certainly due to the vacuum pre-treatment at $400^{\circ} \mathrm{C}$ during one hour.

Adding sodium to $\mathrm{Cu}(6,1 \%) / \mathrm{FER}$ led to the disappearance of $\mathrm{Cu}^{\mathrm{I}}-\mathrm{NO}$. The intensity of $\mathrm{Cu}^{\mathrm{II}}-\mathrm{NO}$ decreased with a shift of the band to lower wavenumber. This shift can be attributed to a change of the copper configuration [73].

To the opposite, adding phosphorus or phosphorus + sodium led to a decrease in the intensity of the $\mathrm{Cu}^{\mathrm{II}}$-NO band without any shift. There was no change in the copper configuration but less accessible $\mathrm{Cu}^{\mathrm{II}}$-NO. These results are consistent with $\mathrm{H}_{2}$-TPR experiments and confirm the assumption of a direct interaction between copper and phosphorus. 

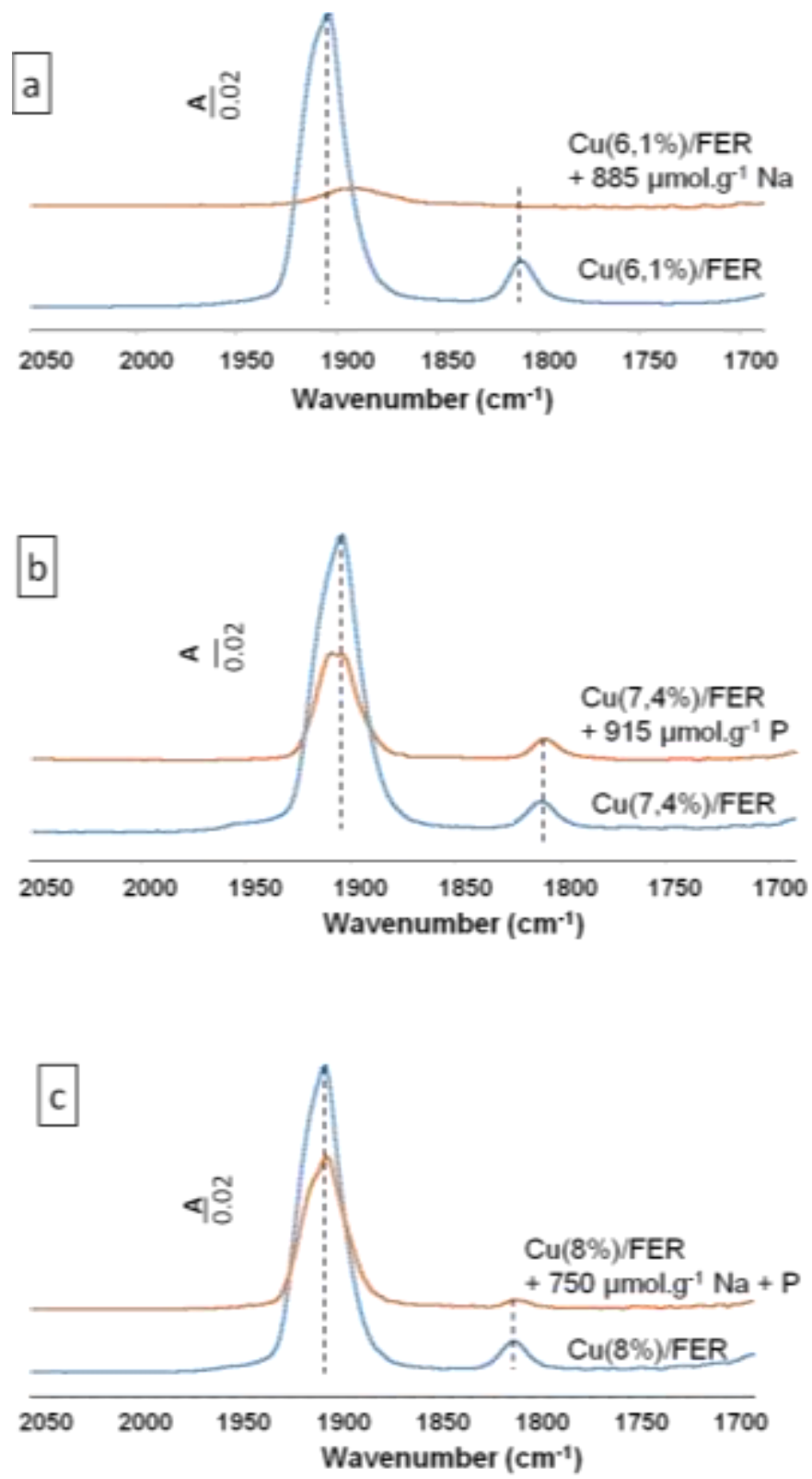

Fig. 6 FTIR spectra of NO adsorption. a: effect of Na deposit over $\mathrm{Cu}(6.1 \%) / \mathrm{FER}$; b: effect of P deposit over $\mathrm{Cu}(7.4 \%) / \mathrm{FER}$; c: effect of $\mathrm{Na}+\mathrm{P}$ over $\mathrm{Cu}(8 \%) / \mathrm{FER}$

The last important parameter for SCR reaction is the acidity $[65,66]$. To assess to this behaviour, $\mathrm{NH}_{3}$ adsorption monitored by FT-IR were performed after activation at $450{ }^{\circ} \mathrm{C}$. Ammonia was adsorbed at $50{ }^{\circ} \mathrm{C}$ and desorption was performed under vacuum at different temperatures. As previously mentioned, $\mathrm{NH}_{3}$ adsorption probably occurs on both acidic sites and copper species. Different bands are observed at $1621 \mathrm{~cm}^{-1}$ and $1452-1397 \mathrm{~cm}^{-1}$ assigned to the Lewis sites (from the zeolite and the copper) and Brønsted acidic sites, respectively (IR spectra not shown). Figure 7a reports the relative remaining ammonia adsorption measured from $\mathrm{NH}_{3}$ evacuated at $100^{\circ} \mathrm{C}$ depending on the inorganic element(s) loading. For the addition of both phosphorus + sodium, two calculations are proposed, considering either 
the total quantity of the two elements added (grey full line) or the equivalent content of only one of the two compounds (grey dotted line).

This figure clearly shows that sodium addition is responsible of the steeper decrease in the amount of adsorbed ammonia, with a loss of more than $80 \%$ of the initial capacity for a Na loading of $885 \mu \mathrm{mol}$ $\mathrm{g}^{-1}$. In addition, IR spectra in the $\mathrm{OH}$ stretching vibration are remarkable by IR bands at 3747,3724 , 3642 and $3602 \mathrm{~cm}^{-1}$, assigned to single terminal $\mathrm{Si}-\mathrm{OH}$ groups, $\mathrm{O}-\mathrm{H}$ stretchings of geminal silanols, $\mathrm{Al}-\mathrm{OH}$ groups and bridging $\mathrm{Al}-(\mathrm{OH})-\mathrm{Si}$ hydroxyls, respectively [74]. It is denoted that adding sodium led to a decrease in the acidity and in particular the Brønsted acidity by the disappearance of $\mathrm{Al}-\mathrm{OH}$ $\left(3642 \mathrm{~cm}^{-1}\right)$ and zeolite hydroxyls groups $\left(3602 \mathrm{~cm}^{-1}\right)$ together with silanols species $\left(3747 \mathrm{~cm}^{-1}\right)$. On the contrary, similar amount of phosphorus induced a decrease in only $15 \%$ of the ammonia adsorption. In accordance with this result, $\mathrm{OH}$ groups are not affected by $\mathrm{P}$ addition (IR spectra, Figure $7 \mathrm{~b}$ ). Note that for intermediate phosphorus loading, an increase in the amount of adsorbed ammonia was observed, which is consistent with results previously described (TPR and oxidation behaviour). Concerning the addition of $(\mathrm{Na}+\mathrm{P})$, a first conclusion aims to propose an intermediate behaviour in terms of acidic poisoning. Indeed, a loss of ammonia adsorption capacity of $40 \%$ is observed for an addition of 750 $\mu$ mol.g $\mathrm{g}^{-1}$ of $\mathrm{Na}+\mathrm{P}$ (full grey line). However, when this deposit is reduced to the corresponding amount of $\mathrm{Na}$ or $\mathrm{P}$ alone (i.e. $375 \mu \mathrm{mol.g}{ }^{-1}$ of each inorganic compound), the observed trend (gray dotted line) is then similar to that denoted by the addition of $\mathrm{Na}$ alone (blue line). It indicates that when phosphorus and sodium are simultaneously deposited, $\mathrm{Na}$ is responsible of the acidity loss. This result confirms that phosphorus addition has very few impact on the adsorption capacity of ammonia.

a

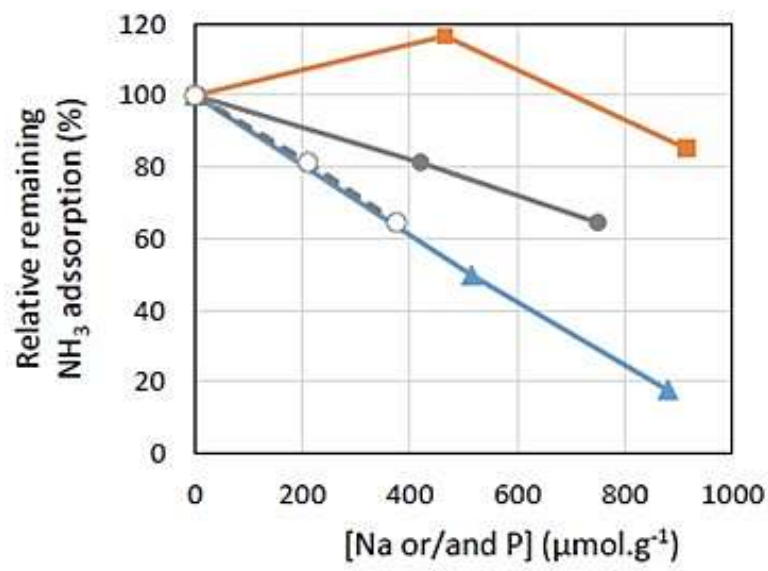

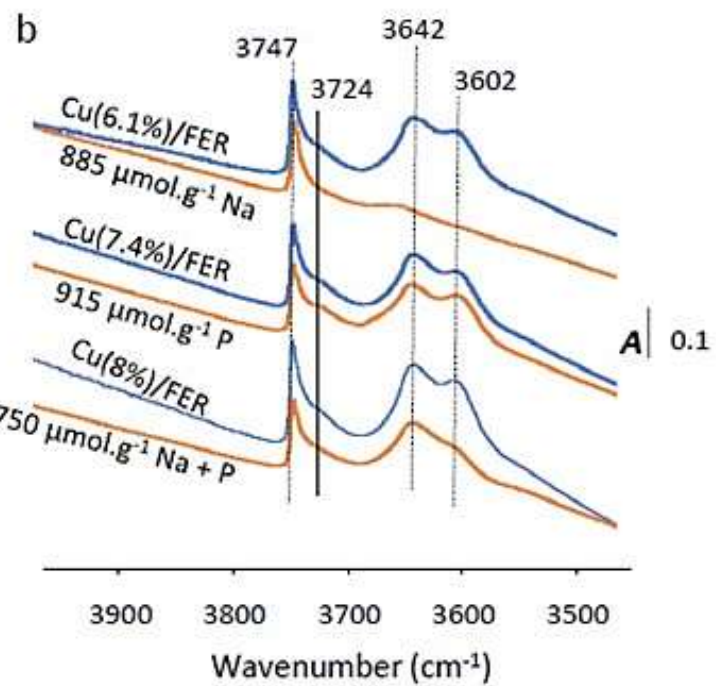

Fig. 7 a): Relative remaining $\mathrm{NH}_{3}$ adsorption (\%) depending on the loading in inorganic elements: $(\Delta)$ : $\mathrm{Na} ;(\square): \mathrm{P} ;(\bigcirc): \mathrm{Na}+\mathrm{P} ;(\bigcirc): \mathrm{Na}+\mathrm{P}$ (singular element); b) corresponding IR spectra for the $\mathrm{OH}$ stretching region. 
To conclude, sodium poisoning leads to a decrease in the SCR deNO efficiency at low and high temperature. The decrease in the activity at $250^{\circ} \mathrm{C}$ can be attributed to loss of the acidity behaviour, whereas the activity at high temperature appeared linked to the disappearance of exchange $\mathrm{Cu}$ species in favour of $\mathrm{CuO}$. Phosphorus poisoning led to a lower copper reducibility (for high $\mathrm{P}$ loading), and the changes were assigned to an interaction between copper and phosphorus. The lower activity at $250^{\circ} \mathrm{C}$ can be explain by this copper-phosphorus interaction whereas the acidity is little affected. The changes in ammonia oxidation behaviour appeared correlated with the changes of the copper reducibility. Adding sodium and phosphorus simultaneously led to a decrease in the activity at low temperature and an almost stable activity at $500^{\circ} \mathrm{C}$. The reducibility and the amount of exchanged copper decreased with the addition of both poisons, as well as the ammonia adsorption capacity. Finally, both poisons are responsible for the catalyst deactivation, but with different impacts. Sodium addition induced a loss in ammonias adsorption capacity associated with change in copper distribution (from exchanged copper to extra framework $\mathrm{CuO}$ ), whereas phosphorus directly interacted with copper. The different results seems to indicate that for the $\mathrm{Na}+\mathrm{P}$ poisoned sample, sodium has a higher impact than phosphorus.

Additionally, as developed in the section 3.1 devoted to the study of DOC performances, the presence of $\mathrm{Na}, \mathrm{K}$ and $\mathrm{P}$ penalise the $\mathrm{NO}_{2}$ production which may affect thereafter the SCR efficiency. Indeed, the expected optimal $\mathrm{NO}_{2} / \mathrm{NO}_{\mathrm{x}}$ ratio is 0.5 corresponding to the fast-SCR condition. The corresponding $\mathrm{NO}_{\mathrm{x}}$ conversion obtained in fast-SCR condition with the fresh $\mathrm{Cu}(8 \%) / \mathrm{FER}$ sample is presented Figure 8 (test performed with $15 \mathrm{mg}$ of catalyst instead of $50 \mathrm{mg}$ for experiments in Standard-SCR condition). As expected, high DeNOx efficiency was obtained (black curve), the $\mathrm{NO}_{\mathrm{x}}$ conversion reached $64 \%$ at $200^{\circ} \mathrm{C}$ (versus $22 \%$ in Standard-SCR condition, with more than three times involved catalyst weight). However, taking into account the $\mathrm{NO}_{2} / \mathrm{NO}_{\mathrm{x}}$ ratio from the fresh DOC sample reported in section 3.1., the DeNOx efficiency brutally dropped, especially at temperature lower than $300-350^{\circ} \mathrm{C}$ (Figure 8, red curve), because the experimental $\mathrm{NO}_{2} / \mathrm{NO}_{\mathrm{x}}$ ratio then ranked between 0.06 and 0.4 . With the presence of $\mathrm{Na}$ and $\mathrm{P}$ on the DOC sample, the $\mathrm{NO}_{2}$ yield decreased again. For instance, the outlet $\mathrm{NO}_{2} / \mathrm{NOx}$ ratio of the poisoned DOC (with $2 \% \mathrm{Na}+6 \% \mathrm{P}$ ) was only 0.09 at $250^{\circ} \mathrm{C}$, compared with 0.21 for the fresh sample. Consequently, the corresponding SCR efficiency furthermore decreased (blue curve). Nevertheless, comparing the fresh and the poisoned DOC, the relative NOx conversion loss at $250^{\circ} \mathrm{C}$ was $24 \%$, while the involved $\mathrm{NO}_{2}$ amount in the SCR reaction was divided by 2 . These results highlight DOC deactivation in $\mathrm{NO}_{2}$ formation does not affect the SCR performances to the same extent. Finally when both DOC and SCR were poisoned (with $2 \% \mathrm{Na}+6 \% \mathrm{P}$ and $0.9 \% \mathrm{Na}+1.2 \% \mathrm{P}$, respectively), high deactivation was achieved (Figure 8, green curve). The $\mathrm{NO}_{\mathrm{x}}$ conversion was devised by 2 at $250^{\circ} \mathrm{C}$ compared with the fresh SCR catalyst associated with the fresh DOC, and by 2.7 compared with the optimal NOx conversion recorded in Fast-SCR condition. 


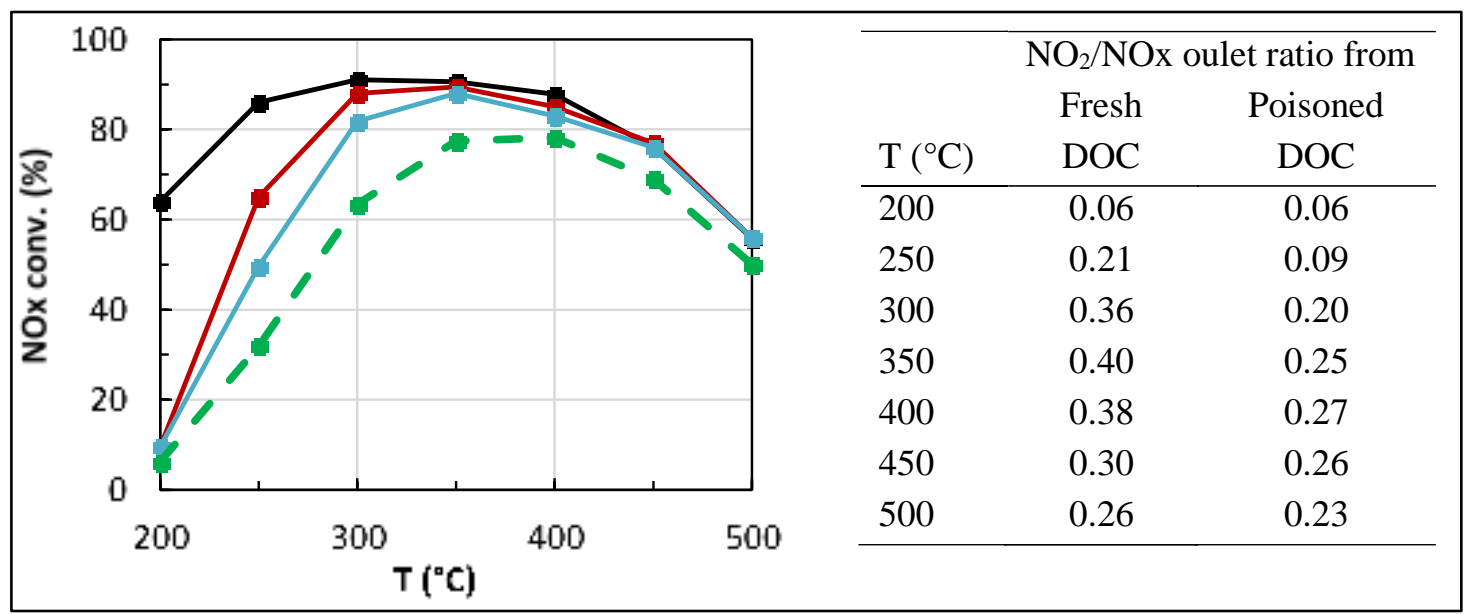

Fig. 8. Influence of the $\mathrm{NO}_{2} / \mathrm{NOx}$ outlet concentration from the DOC on the NOx conversion.

一: Reference in Fast-SCR; - Fresh DOC + Fresh SCR; —: Poisoned DOC (2\% Na + $6 \%$ P) + Fresh SCR; - : Poisoned DOC ( $2 \% \mathrm{Na}+6 \% \mathrm{P})+$ Poisoned SCR $(0.9 \% \mathrm{Na}+1.2 \% \mathrm{P})$. These results were obtained with only $15 \mathrm{mg}$ of catalyst (instead of $50 \mathrm{mg}$ for SCR tests performed in Standard-SCR condition).

\subsection{Diesel Particulate Filter (DPF)}

Soot treatment is carried out by a diesel particulate filter (DPF), for which the regeneration step is crucial. Two pathways for DPF regeneration are conventionally implemented: (i) an active regeneration by oxygen that requires the participation of a catalyst in order to create an exotherm, or (ii) a passive regeneration involving $\mathrm{NO}_{2}$. For both pathways, numerous studies have been conducted in order to elucidate the mechanisms and kinetics of oxidation of the soot generated through the combustion of fossil-based diesel. Here, the aim is to study the impact of biodiesel use on soot properties as well as on the reactivity of soot with respect to $\mathrm{O}_{2}$ and $\mathrm{NO}_{2}$.

Although previous studies have compared soot reactivities according to biodiesel type and content [7578], few information are available regarding the physical chemistry of the particles formed when biofuels are used. To our knowledge, few specific data are available regarding the impact of inorganic matter (K, or P) on soot oxidation. It can nevertheless be expected that the presence of these biodieselspecific compounds would modify the structure and composition of soot and thus its reactivity. The purpose is therefore to characterise the structure, composition and reactivity of the soot generated through biofuel combustion, as a function of the specific features of the model reaction mixture laid down in the specifications of the industrial partner. Once again, the respective roles of alkali metals and of phosphorus are examined following an approach similar to that described previously (elements considered separately and then simultaneously). 


\subsubsection{Production of model and real soot}

\section{Real soot.}

The collection of real soot (DPF scale) was carried out at Renault Trucks on an 8 L heavy goods engine test bench that meets Euro VI specifications and allows the obtainment of soot according to two different defined combustion cycles: a customer cycle and an accelerated loading cycle (combining stationary points and transient cycles). Two commercial types of fuel were used: 7\% biodiesel (standard Euro VI fuel) and 100\% biodiesel (B100 RME EN 14214 from TOTAL). In order to generate reproducible soot, while examining the impact of the content of co-constituent poisons, $\mathrm{K}$ and $\mathrm{P}$ were additivated to the B100 fuel by the introduction of solutions of potassium hydroxide in methanol (1M KOH) and triethyl phosphate. A first batch of fuel with a content of $4 \mathrm{mg} / \mathrm{kg}$ of P, corresponding to the maximum limit of the standard, and $0.3 \mathrm{mg} / \mathrm{kg}$ of $\mathrm{K}$ was prepared. The second batch was enriched in $\mathrm{P}$ and $\mathrm{K}$ up to 28 and $72 \mathrm{mg} / \mathrm{kg}$ respectively, corresponding to 6 and 20 times the standard limits. In the following, these two fuels are named B100+ and B100++ respectively.

Soot were collected on a non-catalytic particulate filter. For engine tests carried out on the customer cycle, an oxidation catalyst (DOC) was placed upstream of the filter in order to ensure realistic soot composition. Soot produced using the accelerated load testing were collected in the absence of DOC. The produced soot with the different engine cycle and fuel will be named in the following X-Y, where $\mathrm{X}$ is the name of the fuel (B7, B100+ or B100++) and Y the name of the cycle (Customer cycle or High loading).

Molecular structure and morphology analyses were performed on the collected soot in the aim of correlating these parameters with reactivity values.

\section{Model soot.}

A fundamental approach was carried out at the IJLRA laboratory. This approach allows model soot production from the combustion of model fuel surrogates using an axisymmetric co-flow diffusion flame burner operating in atmospheric conditions [79,80]. The burner is a Santoro type burner [81]. Soot collection and sampling were carried out in the post-flame region on a glass microfiber filter $(\varnothing=110$ $\mathrm{mm}$ ) after the opening of the flames by reaching the Smoke Point limits. The filter was placed in a glass enclosure in order to isolate it from the surrounding atmosphere. Further details can be found elsewhere [82]. Two Biodiesel surrogates were formulated by adding 30\% (in molar) of two different methyl ester additives: methyl octanoate (MO), and methyl decanoate (MD) to a reference Diesel surrogate (Aref) made up of a binary mixture of 70 mole $\%$ n-decane and 30 mole $\%$ of $\alpha$-methylnaphthalene $(\alpha-M N)$. In order to emphasize the impact of inorganic compounds on soot reactivity, a precursor solution of triethyl phosphate $\left(\left(\mathrm{C}_{2} \mathrm{H}_{5}\right)_{3} \mathrm{PO}_{4}\right)$ was added to each Biodiesel surrogate in a concentration range of $1 \%$ wt. The Biodiesel surrogates enriched in $\mathrm{P}$ will be named in the following MO30+1\% $\mathrm{P}$ and $\mathrm{MD} 30+1 \% \mathrm{P}$.

Finally, soot generated from the combustion of the four selected surrogates will be referred to as MO30, $\mathrm{MD} 30, \mathrm{MO} 30+1 \% \mathrm{P}$ and $\mathrm{MD} 30+1 \% \mathrm{P}$. 


\subsubsection{Experimental}

\section{Characterisation of model and real soot}

The chemical composition of soot samples was measured by CHONS, inductively coupled plasma (ICP) for phosphorus (P) content and atomic absorption spectroscopy (AAS) for potassium (K) element. The structural analysis of model and real soot was carried out using Raman spectroscopy. Thermogravimetric analyses of real and model soot were conducted in the aim of evaluating the SOF and ash contents.

\section{$\underline{\text { Soot reactivity }}$}

The reactivity of real and model soot poisoned by inorganic elements present in the fuel was examined using a continuous-flow fixed-bed synthetic gas bench (SGB). Temperature Programmed Oxidation (TPO) tests from ambient to $700^{\circ} \mathrm{C}$ were performed. Gaseous reaction mixtures of various compositions were implemented in order to simulate the passive regeneration of a DPF (400 ppm NO $2,0-10 \% \mathrm{O}_{2}, 0$ $\left.4 \% \mathrm{H}_{2} \mathrm{O}\right)$

For active regeneration simulation, TPO experiments under $9 \%$ of $\mathrm{O}_{2}$ were performed in a U-shaped quartz reactor (i.d $=8 \mathrm{~mm}$ ) forming a fixed bed of a width of approximately $2 \mathrm{~mm}$ on a porous frit. This later was enclosed inside a thermally isolated furnace. $5 \mathrm{mg}$ of each sample were disposed inside the reactor and flushed with argon (Ar) at room temperature for approximately 15 minutes. The total flow rate through the reactor was $15 \mathrm{NL} \mathrm{h}^{-1}$. Samples were heated up to $750^{\circ} \mathrm{C}$ with a $10^{\circ} \mathrm{C} \mathrm{min}^{-1} \mathrm{ramp}$. Concentrations of $\mathrm{CO}$ and $\mathrm{CO}_{2}$ were measured in the outlet gases by an infrared analyser (Siemens Ultramat6).

\subsubsection{Results}

\section{$\underline{\text { Real soot characterization }}$}

Table 4 presents the chemical composition of the different real soot samples. Comparison of the soot samples composition produced using B7 or B100+ fuels in the same conditions reveals that oxygen content increases when biodiesel content increases. Moreover, oxygen content in soot increases also with $\mathrm{K}$ and $\mathrm{P}$ concentration in the fuel used to produce soot (compare composition of soot produced using B100+ and B100++ with high loading cycle ). In the same way, carbon content decreases when biodiesel content increases and when fuel is enriched in P and K.. Regarding P content, part of this element introduced in the fuel is found in soot. The P concentration ratio in $\mathrm{B} 100+$ and $\mathrm{B} 100++$ soot samples produced during a same high loading cycle is equal to 18 , which is in agreement with the ratio of $\mathrm{P}$ concentration in the two fuel batches ( 72 and $4 \mathrm{mg} / \mathrm{kg}$ ). K content in soot samples is not modified when $\mathrm{B} 100+$ fuel is used as the enrichment is low $(0.3 \mathrm{mg} / \mathrm{kg})$. The low $\mathrm{K}$ concentration measured in B100+-High loading soot sample compared to B100+-Customer cycle soot sample is attributed to the higher exhaust gas temperature obtained in the case of the high loading cycle, thus increasing the mobility of K. The mean temperature of exhaust gases during the High loading cycle was indeed equal 
to $250^{\circ} \mathrm{C}$, with peaks at $330^{\circ} \mathrm{C}$, compared to a temperature range of $130-180^{\circ} \mathrm{C}$ measured during the customer cycle up to the DOC. In a similar way to what is observed with $\mathrm{P}$, a part of $\mathrm{K}$ introduced into biodiesel in a non-negligible concentration (28 ppm) is found in the soot composition (B100++-High loading soot sample).

Thermogravimetric analyses of real soot were carried out under air up to $700^{\circ} \mathrm{C}$ to measure ash content and under nitrogen up to $400^{\circ} \mathrm{C}$ with a $4 \mathrm{~h}$ stage to evaluate organic volatiles contents. As observed on Table 4 the use, during a defined engine cycle, of a fuel enriched with inorganic compounds, increases markedly, by a factor of 3 to 4 , ash content and in a lesser extent the volatile content. In addition one may note that the engine test cycle used for the production of soot also greatly influences soot composition. Customer cycle generates soot with higher ash and volatile content which could be attributed to the lower temperature of exhaust gases during this cycle compared to the high loading cycle.

Table 4. Composition of the different real soot samples.

\begin{tabular}{lccccccc}
\hline Soot sample & $\mathrm{C}^{\mathrm{a}}$ & $\mathrm{H}^{\mathrm{a}}$ & $\mathrm{O}^{\mathrm{a}}$ & $\begin{array}{c}\mathrm{P}^{\mathrm{b}} \\
(\%)\end{array}$ & $\mathrm{K}^{\mathrm{c}}$ & Ash $^{\mathrm{d}}$ & Volatile $^{\mathrm{e}}$ \\
\hline B7-Customer & 89.7 & 1.2 & 3.8 & 0.05 & 0.10 & 1.84 & 3.91 \\
\hline B100+-Customer & 83.1 & 1.3 & 6.2 & 0.19 & 0.10 & 7.78 & 5.56 \\
\hline B100+-High Loading & 84.4 & 0.7 & 7.3 & 0.05 & 0.03 & 1.53 & 0.75 \\
\hline B100++-High Loading & 81.3 & 0.8 & 9.4 & 0.89 & 1.17 & 4.62 & 1.00 \\
a Determined by CHONS & & & & & & \\
b Determined by ICP \\
c Determined by AA \\
${ }^{\mathrm{d}}$ Determined from the mass loss between $20^{\circ} \mathrm{C}$ and $700^{\circ} \mathrm{C}$ in TGA under air \\
${ }^{\mathrm{e}}$ Determined from the mass loss between $110^{\circ} \mathrm{C}$ and $400{ }^{\circ} \mathrm{C}$ in TGA under nitrogen \\
\end{tabular}

First-order spectral region (1000-2000 $\mathrm{cm}^{-1}$ ) of soot Raman spectra were analysed by curve fitting with a combination of four Lorentzian-shaped bands and one Gaussian-shaped band in agreement with recommendation of Sadezky et al. [83]. The obtained results (not presented here) showed that the structure of soot is not really impacted by the presence of $\mathrm{P}$ or $\mathrm{K}$.

Figure 9 presents the evolution of carbon specific oxidation rate obtained during TPO experiments of the different real soot samples in presence of $\mathrm{NO}_{2}(400 \mathrm{ppm}), \mathrm{O}_{2}(10 \%)$ and $\mathrm{H}_{2} \mathrm{O}(4 \%)$ in the feed gas. Whatever the soot sample, ignition temperature is below $200^{\circ} \mathrm{C}$. Similar TPO profiles were obtained for all soot produced using B7 and B100+ fuel, whatever the applied engine cycle. Two main peaks are observed at temperatures higher than $400^{\circ} \mathrm{C}$ with an additional smaller one at lower temperatures ( 280$290^{\circ} \mathrm{C}$ ). This latter, also observed when TPO experiments were performed with a feed gas composed of $400 \mathrm{ppm} \mathrm{NO} / \mathrm{N}_{2}$ (Figure 10), is attributed to the oxidation of volatile compounds in agreement with previous results presented in the literature [84]. On figures 9 and 10, this peak is particularly clear with soot produced during the customer cycle, which presents the highest volatile content (Table 4). The two 
peaks with temperatures of maximum emission $\left(\mathrm{T}_{\max }\right)$ around $500^{\circ} \mathrm{C}$ and $600^{\circ} \mathrm{C}$ are attributed to the existence of different carbon sites. As already mentioned in a previous study [82] soot oxidation observed around $500^{\circ} \mathrm{C}$ is attributed to the presence of amorphous carbon sites while the peak around $600^{\circ} \mathrm{C}$ is linked to the oxidation of more structured carbon sites. In Figure 9, a shift of $\mathrm{T}_{\max }$ to lower temperatures is observed for the different soot samples as follows: B7-customer cycle > B100+Customer cycle > B100+-High loading cycle. When soot are burnt under a gas flow composed of $9 \%$ $\mathrm{O}_{2} / \mathrm{N}_{2}$, simulating an active regeneration, the effect of fuel composition (B7 or B100+) is also observed (Figure 11). However, in that case, no impact of the engine cycle could be highlighted.

Compared to B7 or B100+ sample, the reactivity of B100++-High loading soot is greatly enhanced. Under a feed gas composed of only $\mathrm{NO}_{2}$ (Figure 10) B100++-High loading soot exhibits a higher reactivity with a decrease in $\mathrm{T}_{\max }$ of $55^{\circ} \mathrm{C}$ and $35^{\circ} \mathrm{C}$ compared to $\mathrm{B} 7-\mathrm{Customer}$ cycle and $\mathrm{B} 100+$-High loading soot samples respectively. Under a gas flow composed of $9 \% \mathrm{O}_{2} / \mathrm{N}_{2}$, no additional impact of the enrichment of the fuel by $\mathrm{K}$ and $\mathrm{P}$ is observed on $\mathrm{T}_{\max }$ but a complete oxidation of B100++-High loading soot sample at temperature lower than $700^{\circ} \mathrm{C}$ is obtained (Figure 11). Introduction of $\mathrm{O}_{2}$ and $\mathrm{H}_{2} \mathrm{O}$ together with $\mathrm{NO}_{2}$ in the reactive gas flow (Figure 9) enables a complete oxidation of the B100++High loading soot sample at $600^{\circ} \mathrm{C}$, while a temperature higher than $635^{\circ} \mathrm{C}$ is needed for other samples. The shape of TPO profile obtained with soot produced from the enriched B100++ fuel is also greatly different (Figure 9). Only two peaks, a broad one in the temperature range $200-450^{\circ} \mathrm{C}$ and a second one with $\mathrm{T}_{\max }$ at $550^{\circ} \mathrm{C}$, are observed. The obtained TPO profiles (Figures 9 and 10) are similar to those obtained, in the same experimental conditions, with carbon black samples doped with alkali metals (Na or K) or phosphorus [85]. In this work, which aimed to evaluate the influence of the presence of inorganic compounds, on the reactivity of a model soot (Carbon Black) [85], it was observed that alkali metals exhibit a beneficial effect on the carbon oxidation process though the whole temperature range, regardless the reactive gas flow composition. Both active (by $\mathrm{O}_{2}$ ) and passive (in presence of $\mathrm{NO}_{2}$ ) carbon oxidation reaction rates are increased by $\mathrm{Na}$ or $\mathrm{K}$ elements. Moreover, it was observed that impregnation of carbon black samples by phosphorus has no impact on the mechanism and kinetic of $\mathrm{C}-\mathrm{NO}_{2}$ reaction. However, in presence of water in the feed gas, carbon oxidation rate is enhanced at low temperatures when carbon black is doped with P. This behaviour was attributed to the formation of phosphoric acid which induces a catalytic effect on carbon oxidation, in a similar way as the well-known catalytic effect of water on carbon oxidation [86,87]. Results presented in the present paper with real soot agree with those obtained on carbon black samples. Indeed, the special behaviour of B100++-High loading soot under a gas flow composed of $\mathrm{O}_{2}, \mathrm{NO}_{2}$ or $\mathrm{NO}_{2}+\mathrm{O}_{2}+\mathrm{H}_{2} \mathrm{O}$ could be correlated to the presence of $\mathrm{P}$ and $\mathrm{K}$ in the composition of these soot (Table 4). K exerts a catalytic effect on the oxidation process though the whole temperature range and particularly at high temperature $\left(>450^{\circ} \mathrm{C}\right)$ for $\mathrm{C}-\mathrm{O}_{2}$ and C-NO $\mathrm{N}_{2}$ reactions while $\mathrm{P}$ enhances $\mathrm{C}-\mathrm{NO}_{2}$ reaction in the temperature range $200-400^{\circ} \mathrm{C}$ in presence of $\mathrm{H}_{2} \mathrm{O}$ in the feed gas. 


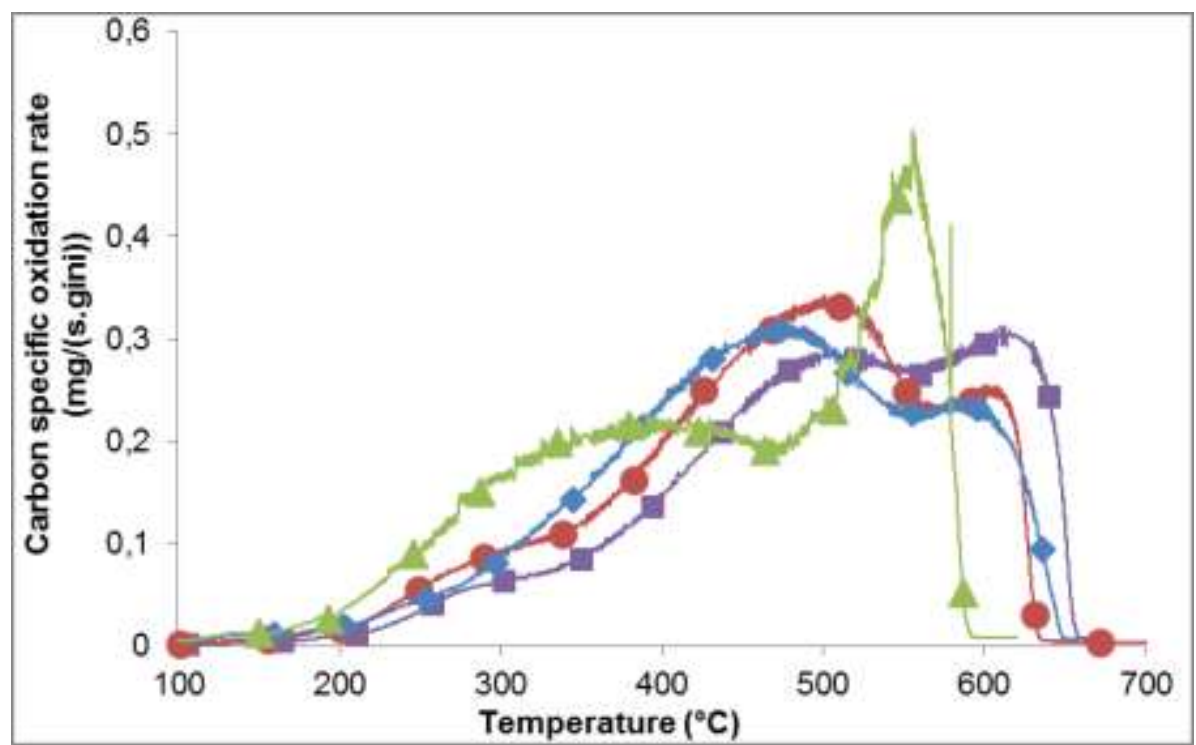

Fig. 9 TPO profiles of real soot samples under $\mathrm{NO}_{2}$ (400 ppm), $\mathrm{O}_{2}(10 \%)$ and $\mathrm{H}_{2} \mathrm{O}$ (4 \%). (口): $\mathrm{B} 7-$ Custumer; $(\bigcirc)$ : B100+-Custumer; $(\diamond)$ : B100+-High Load; $(\triangle)$ : B100++-High Load

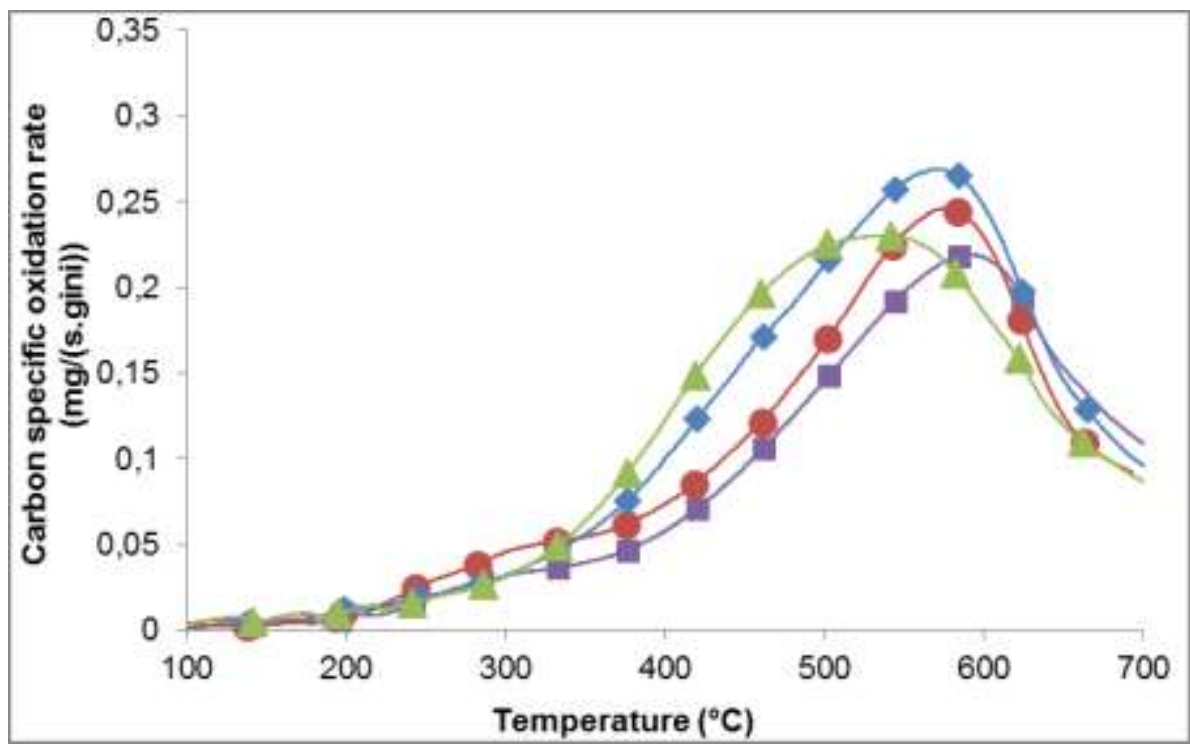

Fig. 10 TPO profiles of real soot samples under $\mathrm{NO}_{2}$ (400 ppm). (ロ): B7-Custumer; (๑): B100+Custumer; $(\diamond)$ : B100+-High Load; $(\triangle)$ : B100++-High Load 


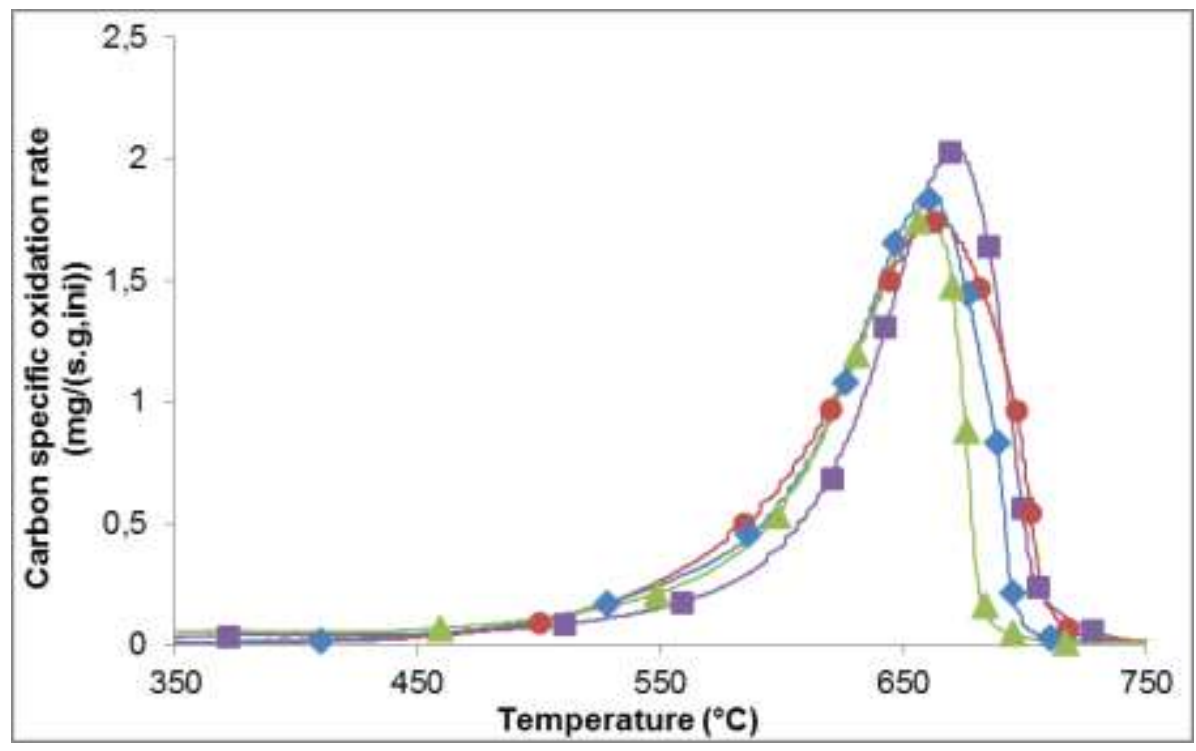

Fig. 11 TPO profiles of real soot samples under $\mathrm{O}_{2}(9 \%)$. ( $\square$ ): B7-Custumer; ( ): B100+-Custumer; $(\diamond)$ : B100+-High Load; ( $\triangle$ ): B100++-High Load

\section{Model soot characterization}

The chemical composition of the poisoned model soot is presented in Table 5. It can be noticed that oxygen content increases in the soot when Biodiesel surrogates MO30 and MD30 were poisoned by P. These observations are in agreement with results found on real Diesel soot even if the relative percentages of the chemical elements $\mathrm{O}$ and $\mathrm{P}$ are much higher in the poisoned model soot suggesting that the transfer of $\mathrm{P}$ from the fuel to the soot is more important using the diffusion flame burner. In addition, it can be observed that both SOF and ash content of MO30+1\% $\mathrm{P}$ and MD30+1\% $\mathrm{P}$ exhibit the same tendency as the one found for real soot: an increase when P is added to the fuel (see Table 5).

Table 5. Model soot composition.

\begin{tabular}{ccccccc}
\hline Soot sample & $\mathrm{C}^{1}$ & $\mathrm{H}^{1}$ & $\mathrm{O}^{1}$ & $\mathrm{P}^{2}$ & Ash $^{3}$ & Volatile $^{4}$ \\
\hline MO30 & 89.7 & 1.0 & 3.6 & n.m. & 0.09 & 2.39 \\
\hline MO30+1\%P & 55.2 & 1.7 & 16.7 & 7.36 & 16.33 & 7.75 \\
\hline MD30 & 91.4 & 0.8 & 3.2 & n.m. & 0.62 & 1.45 \\
\hline MD30+1\%P & 48.2 & 2.0 & 17.2 & 6.75 & 12.00 & 6.84
\end{tabular}

${ }^{1}$ Determined by CHONS

${ }^{2}$ Determined by ICP

${ }^{3}$ Determined from the mass loss between 20 and $700^{\circ} \mathrm{C}$ in TGA under air

${ }^{4}$ Determined from the mass loss between 110 and $400^{\circ} \mathrm{C}$ in TGA under nitrogen

In order to evaluate the impact of $\mathrm{P}$ poisoning on soot oxidative reactivity, model soot have undergone several temperature programmed oxidation reactions under different oxidizing gas mixtures. 
Figures 11 to 13 show TPO profiles of poisoned and non-poisoned model soot under gas flows composed of $9 \%$ of $\mathrm{O}_{2}$ in $\mathrm{N}_{2}, 400 \mathrm{ppm}$ of $\mathrm{NO}_{2}$ in $\mathrm{N}_{2}$ and a mixture containing $400 \mathrm{ppm} \mathrm{NO}_{2}+10 \% \mathrm{O}_{2}+4 \% \mathrm{H}_{2} \mathrm{O}$ in $\mathrm{N}_{2}$ respectively. As it can be seen in Figure 12 the rate of soot oxidation under $9 \% \mathrm{O}_{2} / \mathrm{N}_{2}$ decreases in presence of phosphorus. This decrease can be explained by the low percentage of carbon soot obtained when generating poisoned soot through the burner (see Table 5). Moreover, it can be observed that the high percentage of phosphorus ( $7 \%$ approximately) contained in poisoned model soot MO30+1\% $\mathrm{P}$ and $\mathrm{MD} 30+1 \% \mathrm{P}$ has no effect on the maximum temperature oxidation peak but inhibits the light-off temperature of soot oxidation by $\mathrm{O}_{2}$ (Figure 12). Therefore a temperature higher than $750^{\circ} \mathrm{C}$ is needed to completely oxidize $\mathrm{MO} 30+1 \% \mathrm{P}$ and $\mathrm{MD} 30+1 \% \mathrm{P}$ soot samples while a lower temperature, at around $720-750^{\circ} \mathrm{C}$, is needed for non-poisoned MO30 and MD30 soot samples. Such result could be attributed to the high affinity of $\mathrm{P}$ with oxygen, and so the formation of strong $\mathrm{P}-\mathrm{O}$ type bonds that resist soot oxidation by $\mathrm{O}_{2}$.

Under a gas mixture containing $400 \mathrm{ppm}$ of $\mathrm{NO}_{2}$ in $\mathrm{N}_{2}$, the oxidation of poisoned model soot is shifted towards lower temperatures indicating higher reactivity when phosphorus is embedded in the soot structure (Figure 13). These results correlate well with those obtained with real soot in the same conditions. Nevertheless, the gap of the maximum temperature oxidation between non-poisoned and poisoned soot is more pronounced for model soot $\left(100^{\circ} \mathrm{C}\right)$ than the real soot $\left(55^{\circ} \mathrm{C}\right)$. This can be attributed to the higher percentages of $\mathrm{P}$ and $\mathrm{O}$ contained in model soot.

Finally, and based on Figure 14, we can report that $\mathrm{P}$ exerts a catalytic effect on the oxidation process of the poisoned model soot in the presence of water in the feed gas, in agreement with the behaviour recorded in the case of poisoned real soot B100++-High Loading.

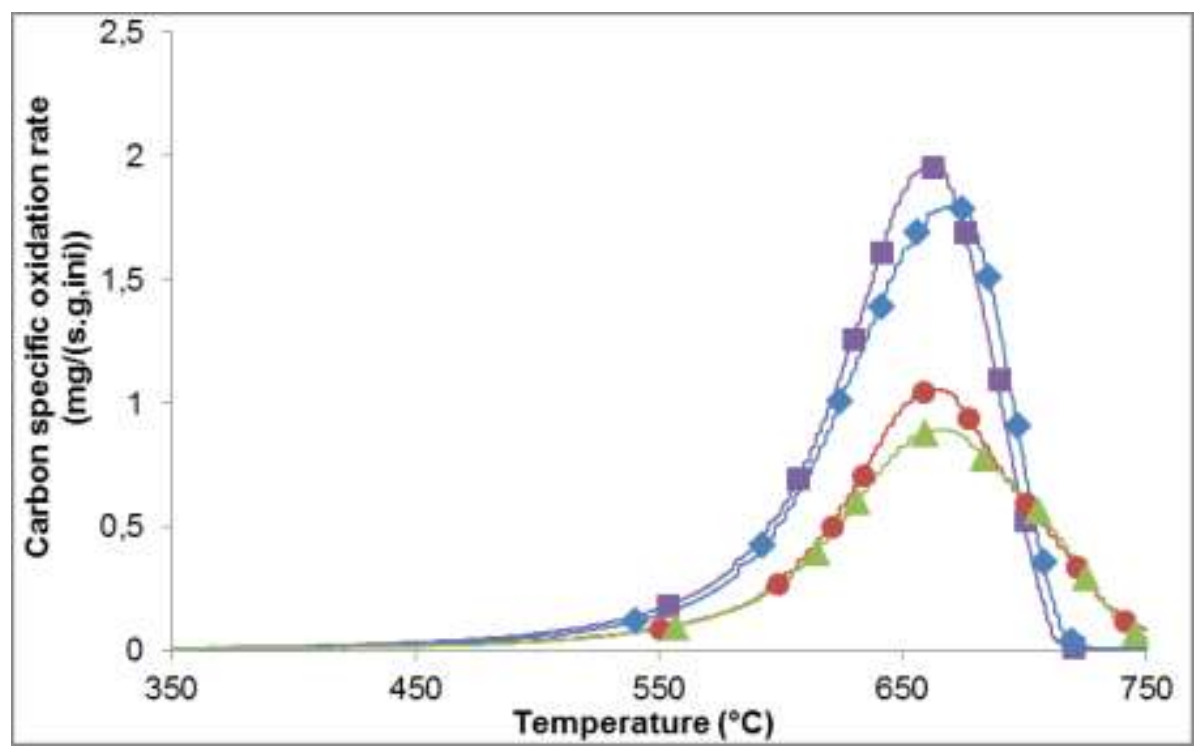

Fig. 12 TPO profiles of model soot samples under $\mathrm{O}_{2}(9 \%)$. (ロ): $\mathrm{MO} 30 ;(\bullet)$ : $\mathrm{MO} 30+1 \% \mathrm{P} ;(\diamond)$ : MD30; ( $\triangle$ ): MD30+1\%P 


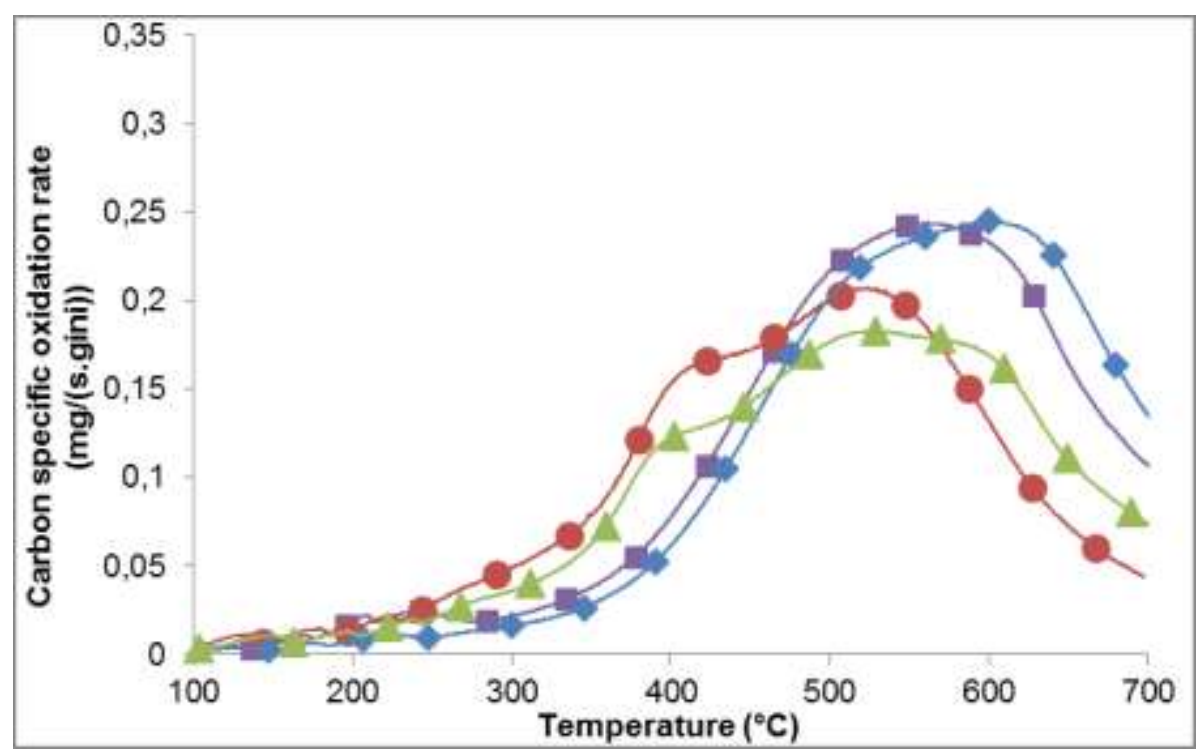

Fig. 13 TPO profiles of model soot samples under $\mathrm{NO}_{2}$ (400 ppm). ( $\square$ ): $\mathrm{MO} 30 ;(\bullet)$ : $\mathrm{MO} 30+1 \% \mathrm{P} ;(\diamond)$ : MD30; ( $\triangle)$ : MD30+1\%P

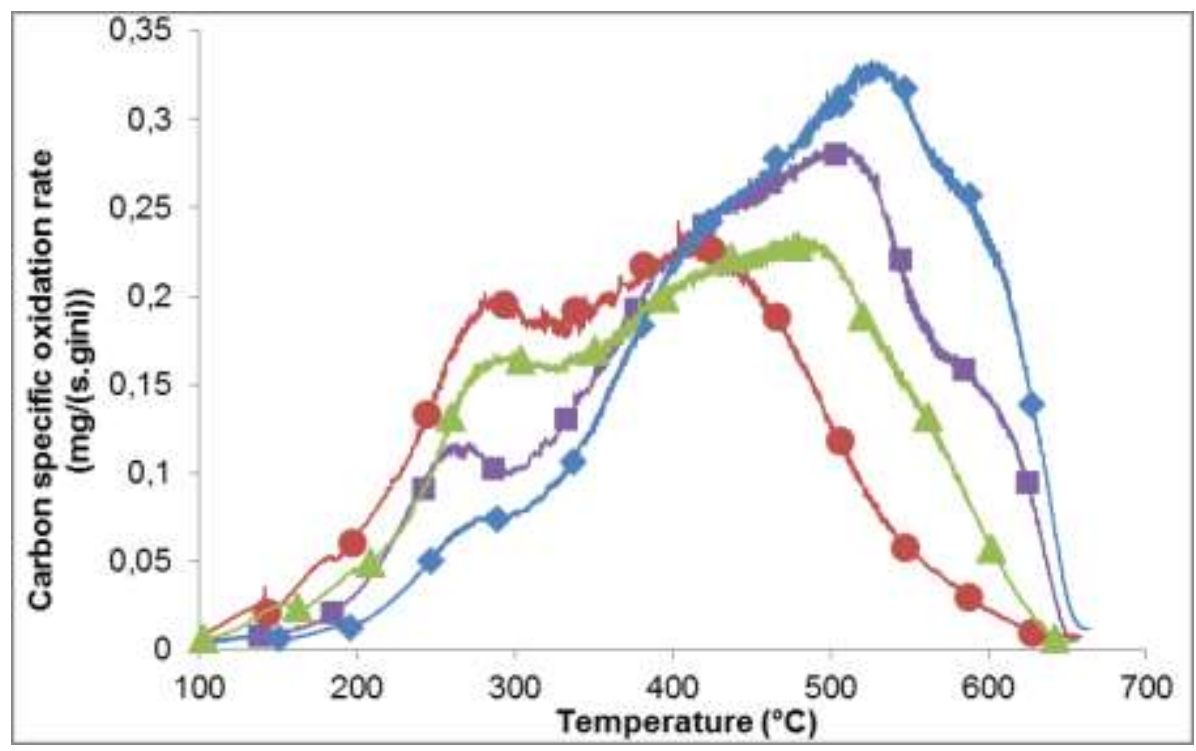

Fig. 14 TPO profiles of model soot samples under $\mathrm{NO}_{2}$ (400 ppm), $\mathrm{O}_{2}(10 \%)$ and $\mathrm{H}_{2} \mathrm{O}(4 \%)$. (口): MO30; $(\bullet): \mathrm{MO} 30+1 \% \mathrm{P} ;(\diamond): \mathrm{MD} 30 ;(\Delta): \mathrm{MD} 30+1 \% \mathrm{P}$

\section{Conclusions and perspectives}

The effect of the three main inorganic elements from biodiesel, namely sodium, potassium and phosphorus, was investigated on the three exhaust pipe depollution processes. This study pointed out the possible negative or positive effects of these elements, which may impact the durability of the existing Euro VI catalytic systems.

Concerning soot combustion, real soot and on carbon black samples exhibited the same trends: alkali metals exhibited a catalytic effect, regardless the reactive gas flow composition, i.e. using either active 
(by $\mathrm{O}_{2}$ ) or passive (in presence of $\mathrm{NO}_{2}$ ) oxidation condition. Samples containing phosphorus exhibited an enhancement of the oxidation rate in presence of water in the feed gas. It was attributed to the formation of phosphoric acid. Moreover, phosphorus had no impact on the mechanism and kinetic of C$\mathrm{NO}_{2}$ reaction for carbon black samples. Nevertheless, the gap of the maximum temperature oxidation between non-poisoned and poisoned soot is more pronounced for model soot $\left(100^{\circ} \mathrm{C}\right)$ than the real soot $\left(55^{\circ} \mathrm{C}\right)$. This can be attributed to the higher percentages of $\mathrm{P}$ and $\mathrm{O}$ contained in model soot.

For a copper exchanged-zeolite SCR catalyst, sodium poisoning led to a decrease in the SCR deNO efficiency at low and high temperature. The decrease in the activity at $250^{\circ} \mathrm{C}$ can be attributed to loss of the acidity behaviour, whereas the activity at high temperature appeared linked to the disappearance of exchange $\mathrm{Cu}$ species in favour of $\mathrm{CuO}$. Phosphorus poisoning led to a lower copper reducibility (for high P loading), and the changes were assigned to a direct interaction between copper and phosphorus. Adding sodium and phosphorus simultaneously with the same molar loading, both poisons are responsible for the catalyst deactivation, but results seemed to indicate that sodium has a higher impact than phosphorus.

In a Euro VI exhaust pipe configuration, the first catalytic system is the DOC. Propene and carbon monoxide light-off temperatures appeared not really influenced by inorganic elements addition. However, alkali compounds negatively impacted the $\mathrm{NO}_{2}$ production, which would affect the effectiveness of the DPF passive regeneration and the efficiency the SCR system by limitation of the desired Fast-SCR reaction.

Because on-board catalysts are likely to be subjected to strong variations in temperature and atmospheric composition (oxidising/reducing), the impact of these criteria has to be carefully examined on the catalytic systems. The objective will be thus to determine whether these treatments could have an additional negative impact (reactivity, physico-chemical characteristics) or if they could lead to a certain degree of regeneration.

Finally, these results will be used to refine the models belonging to Renault Trucks that describe the behaviour of the pollution control system over time, in order to add an overall predictive model of deactivation based on biofuel use rate. It would provide information for the appropriate dimensioning of Euro VI exhaust lines as well as future Euro VII lines, in order to guarantee the required durability while taking the biofuel aspect into account.

\section{Acknowledgement}

The authors gratefully acknowledge the French National Agency (ANR) for Research for its financial support (Appibio Project, Ref. ANR-14-CE22-0003). 


\section{References}

[1] https://www.iso.org/standard/40793.html

[2] Colombo, M., Nova, I., Tronconi, E.: A comparative study of the $\mathrm{NH}_{3}-\mathrm{SCR}$ reactions over a $\mathrm{Cu}$ zeolite and a Fe-zeolite catalyst. Catal. Today 151, 223-230 (2010)

[3] Ottinger, N., Nguyen, K., Bunting, B., Toops, T., Howe, J.: Effects of Rapid High Temperature Cyclic Aging on a Fully-Formulated Lean NOx Trap Catalyst. SAE Int. J. Fuels Lubr. 2(1), 217-228 (2009)

[4] Choi, B., Liu, B., Jeong, J.: Effects of hydrothermal aging on SiC-DPF with metal oxide ash and alkali metals. J. Ind. Eng. Chem. 15, 707-715 (2009)

[5] Cavataio, G., Jen, H., Girard, J., Dobson, D., Warner, J.R., Lambert, C.K.: Impact and Prevention of Ultra-Low Contamination of Platinum Group Metals on SCR Catalysts Due to DOC Design. SAE Int. J. Fuels Lubr. 2(1) 204-216 (2009)

[6] Theis, J., Ura, J., McCabe, R.: The Effects of Sulfur Poisoning and Desulfation Temperature on the NOx Conversion of LNT+SCR Systems for Diesel Applications. SAE Int. J. Fuels Lubr. 3(1) 1-15 (2010).

[7] Kamasamudram, K., Currier, N., Szailer, T., and Yezerets, A.: Why Cu- and Fe-Zeolite SCR Catalysts Behave Differently At Low Temperatures. SAE Int. J. Fuels Lubr. 3(1), 664-672 (2010)

[8] Epling, W.S., Campbell, L.E., Yezerets, A., Currier, N.W., Parks II, J.E.: Overview of the Fundamental Reactions and Degradation Mechanisms of NOx Storage/Reduction Catalysts. Catal. Rev. 46, 163-245 (2005)

[9] Benramdhane, S., Millet, C.N,. Jeudy, E., Lavy, J., Blasin Aubé, V., Daturi, M.: Impact of thermal and vehicle aging on the structure and functionalities of a lean NOx-trap. Catal. Today 176, 56-62 (2011) [10] Le Phuc, N., Corbos, E.C., Courtois, X., Can, F., Marecot, P., Duprez D.: NOx storage and reduction properties of $\mathrm{Pt} / \mathrm{Ce}_{\mathrm{x}} \mathrm{Zr}_{1-\mathrm{x}} \mathrm{O}_{2}$ mixed oxides: Sulfur resistance and regeneration, and ammonia formation. Appl. Catal. B 93, 12-21 (2009)

[11] Szybist, J.P., Song, J., Alam, M., Boehman A.L.: Biodiesel combustion, emissions and emission control. Fuel Process. Technol. 88, 679-691 (2007)

[12] Graboski, M.S., McCormick, R.L.: Combustion of fat and vegetable oil derived fuels in diesel engines. Prog. Energy Combust. Sci. 24, 125-164 (1998)

[13] Szybist, J.P., Boehman, A.L,. Haworth, D.C., Koga, H.: Premixed ignition behavior of alternative diesel fuel-relevant compounds in a motored engine experiment. Combust. Flame 149, 112-128 (2007) [14] Wang, X., Cheung, C.S., Di, Y., Huang, Z.: Diesel engine gaseous and particle emissions fueled with diesel-oxygenate blends. Fuel 94, 317-323 (2012)

[15] Millo, F., Vezza, D.S., Vlachos, T., De Filippo, A., Ciaravino, C., Russo, N., Fino, D.: Particle Number and Size Emissions from a Small Displacement Automotive Diesel Engine: Bioderived vs Conventional Fossil Fuels. I\&EC 51, 7565-7572 (2012)

[16] Tatur, M., Nanjundaswamy, H., Tomazic, D., Thornton, M., McCormick, R.L.: Biodiesel Effects on U.S. Light-Duty Tier 2 Engine and Emission Control Systems - Part 2. SAE Int. J. Fuels Lubr. 2(1), 88-103 (2009)

[17] Fraer, R., Dinh, H., Proc, K., McCormick, R., Chandler, K., Buchholz, B.: Operating Experience and Teardown Analysis for Engines Operated on Biodiesel Blends (B20). SAE Technical Paper 200501-3641 (2005).

[18] Ballesteros, R., Monedero, E., Guillen-Flores, J.: Determination of aldehydes and ketones with high atmospheric reactivity on diesel exhaust using a biofuel from animal fats. Atmo. Env. 45, 2690-2698 (2011) 
[19] Cosseron, A., Tschamber, V., Coniglio, L., Daou, TJ.: Study of Non-Regulated Exhaust Emissions Using Biodiesels and Impact on a 4 Way Catalyst Efficiency. SAE Technical Paper 2011-24-0194 (2011)

[20] Prasomsri, T., To, A.T., Crossley, S., Alvarez, W.E., Resasco, D.E.: Catalytic conversion of anisole over HY and HZSM-5 zeolites in the presence of different hydrocarbon mixtures. Appl. Catal. B 106, 214-211 (2011)

[21] Adouane, D., Capela, S., Da Costa, P.: On the Efficiency of NH3-SCR Catalysts for Heavy Duty Vehicles Running on Compressed Natural Gas in Synthetic Gas Bench Scale. Top. Catal. 56, 45-49 (2013)

[22] Joubert, E., Courtois, X., Marécot, P., Duprez, D.: NO reduction by hydrocarbons and oxygenated compounds in $\mathrm{O}_{2}$ excess over a $\mathrm{Pt} / \mathrm{Al}_{2} \mathrm{O}_{3}$ catalyst: A comparative study of the efficiency of different reducers (hydrocarbons and oxygenated compounds). Appl. Catal. B 64, 103-110 (2006)

[23] Can, F., Travert, A., Ruaux, V., Gilson, J.P., Maugé, F., Hu, R., Wormsbecher, R.F.: FCC gasoline sulfur reduction additives: Mechanism and active sites. J. Catal. 249, 79-92 (2007)

[24] Kanerva, T., Kroger, V., Rahkamaa-Tolonen, K., Vippola, M., Lepisto, T., Keiski, R.L.: Structural changes in air aged and poisoned diesel catalysts. Top. Catal. 45, 137-142 (2007)

[ 25 ] Kroger, V., Kanerva, T., Lassi, U., Rahkamaa-Tolonen, K., Vippola, M., Keiski, R.L.: Characterization of phosphorus poisoning on diesel exhaust gas catalyst components containing oxide and Pt. Top. Catal.45, 153-157 (2007)

[26]Williams, F.L., Baron, K.: Lead, sulfur and phosphorus interactions with platinum and palladium metal foils. J. Catal. 40, 108-116 (1975)

[27] Matam, S.K., Kondratenko, E.V., Aguirre, M.H., Hug, P., Rentsch, D., Winkler, A., Weidenkaff, A., Ferri, D.: The impact of aging environment on the evolution of $\mathrm{Al}_{2} \mathrm{O}_{3}$ supported $\mathrm{Pt}$ nanoparticles and their NO oxidation activity. Appl. Catal. B 129, 214- 224 (2013)

[28] Hoekman, S.K., Robbins, C.: Review of the effects of biodiesel on NOx emissions. Fuel Proc. Tech. 96, 237-249 (2012

[29] Xue, J., Grift, T.E., Hansen, A.C.: Effect of biodiesel on engine performances and emissionsRenew. Sust. Energy Rev. 15, 1098-1116 (2011)

[30] Apostolescu, N., Geiger, B., Hizbullah, K., Jan, M.T., Kureti, S., Reichert, D., Schott, F., Weisweiler, W.: Selective catalytic reduction of nitrogen oxides by ammonia on iron oxide catalysts. Appl. Catal. B 62, 104-114 (2006)

[31] Luo, J.Y., Hou, X., Wijayakoon, P., Schmieg, S.J., Li, W., Epling, W.S.: Spatially resolving SCR reactions over a Fe/zeolite catalyst. Appl. Catal. B 102, 110-119 (2011)

[32] Ozkan, U.S., Cai, Y., Kumthekar, M.W.: Investigation of the Reaction Pathways in Selective Catalytic Reduction of $\mathrm{NO}$ with $\mathrm{NH}_{3}$ over $\mathrm{V}_{2} \mathrm{O}_{5}$ Catalysts: Isotopic Labeling Studies Using ${ }^{18} \mathrm{O}_{2},{ }^{15} \mathrm{NH}_{3}$, ${ }^{15} \mathrm{NO}$, and ${ }^{15} \mathrm{~N}^{18} \mathrm{O}$. J. Catal. 149, 390-403 (1994)

[33] Odenbrand, C.U.I., Bahamonde, A., Avila, P., Blanco, J.: Kinetic study of the selective reduction of nitric oxide over vanadia - tungsta - titania/sepiolite catalyst. Appl. Catal. B 5, 117-131 (1994)

[34] Ramis, G., Busca, G., Bregani, F., Forzatti, P.: Fourier transform-infrared study of the adsorption and coadsorption of nitric oxide, nitrogen dioxide and ammonia on vanadia-titania and mechanism of selective catalytic reduction. Appl. Catal 64, 259-278 (1990)

[35] Kiel, J.H.A., Edelaar, A.C.S., Prins, W., Van Swaaij, W.P.M.: Performance of silica-supported copper oxide sorbents for SOx/NOx-removal from flue gas: II. Selective catalytic reduction of nitric oxide by ammonia. Appl. Catal. B 1, 41-60 (1992)

[36] Bosch, H., Janssen, F.: Formation and control of nitrogen oxides. Catal. Today 2, 369-379 (1988).

[37] Skalza, K., Miller, J.S., Ledakowicz, S., Trends in NOx abatement: A review. Sci. Total Environ. 408, 3976-3989 (2010) 
[38] Wan, Q., Duan, L., Li, J., Chen, L., He, K., Hao, J.: Deactivation performance and mechanism of alkali (earth) metals on $\mathrm{V}_{2} \mathrm{O}_{5}-\mathrm{WO}_{3} / \mathrm{TiO}_{2}$ catalyst for oxidation of gaseous elemental mercury in simulated coal-fired flue gas. Catal. Today 175, 189-195 (2011)

[39] Larsson, A.C., Einvall, J., Andersson, A., Sanati, M.: Physical and chemical characterisation of potassium deactivation of a SCR catalyst for biomass combustion. Top. Catal. 45, 149-152 (2007)

[40] Yu, Y.K., He, C., Chen, J.S., Meng, X.R.: Deactivation mechanism of de-NOx catalyst $\left(\mathrm{V}_{2} \mathrm{O}_{5^{-}}\right.$ $\mathrm{WO}_{3} / \mathrm{TiO}_{2}$ ) used in coal fired power plant. J. Fuel Chem. Tec, 40, 1359-1365 (2012)

[41] Zheng, Y., Jensen, A.D., Johnsson, J.E., Thøgersen, J.R.: Deactivation of $\mathrm{V}_{2} \mathrm{O}_{5}-\mathrm{WO}_{3}$-TiO2 $\mathrm{SCR}$ catalyst at biomass fired power plants: Elucidation of mechanisms by lab- and pilot-scale experiments. Appl. Catal. B 83, 186-194 (2008)

[42] Putluru, S.S.R., Kristensen, S.B., Due-Hansen, J. Riisager, A.: Alternative alkali resistant deNOx catalysts. Catal. Today 184, 192-196 (2012)

[43] Nova, I., Dall'Acqua, L.,Lietti, L., Giamello, E., Forzatti, P.: Study of thermal deactivation of a deNOx commercial catalyst. Appl. Catal. B 35, 31-42 (2001)

[44] Chapmann, D.M.: US patent 2011/0138789 A1 (2011)

[45] Blanchard, G., Rousseau, S., Mazri, L., Lizarraga, L., Giroir-Fendler, A., D’anna, B., Vernoux, P.: European Patent 11708906.0-2113 (2011)

[46] Park, J. H., Park, H.J., Baik, J.H., Nam, I.S., Shin, C.H., Lee, J.H., Cho, B.K., Oh S.H.: Hydrothermal stability of CuZSM5 catalyst in reducing $\mathrm{NO}$ by $\mathrm{NH}_{3}$ for the urea selective catalytic reduction process. J. Catal. 240, 47-57 (2006)

[47] Sullivan, J.A., Keane, O.: The role of Bronstead acidity in poisoning the SCR-urea reaction over FeZSM-5 catalysts. Appl. Catal. B 61, 244-252 (2005)

[48] Guan, B., Zhan, R., Lin, H., Huang, Z.: Review of state of the art technologies of selective catalytic reduction of NOx from diesel engine exhaust. Appl. Therm. Eng. 66, 395-414 (2014).

[49] Brookhear, D.W., Nguyen, K., Toops, T.J., Bunting, B.G., Rorh, W.F., Howe, J.: Investigation of the effects of biodiesel-based $\mathrm{Na}$ on emissions control components. Catal. Today 184, 205-218 (2012)

[50] Agarwal, A.K., Gupta, T., Kothari A.: Particulate emissions from biodiesel vs diesel fuelled compression ignition engine. Renew. Sust. Energy Rev. 15, 3278-3300 (2011)

[51] Sharp, C., Howell, S., and Jobe, J.: The Effect of Biodiesel Fuels on Transient Emissions from Modern Diesel Engines, Part I Regulated Emissions and Performance. SAE Technical Paper 2000-011967 (2000)

[52] A Sappok, A. and Wong, V.: Impact of Biodiesel on Ash Emissions and Lubricant Properties Affecting Fuel Economy and Engine Wear: Comparison with Conventional Diesel Fuel. SAE Int. J. Fuels Lubr. 1(1), 731-747 (2009)

[53] Williams, A., McCormick, R., Luecke, J., Brezny, R. Geisselmann, A., Voss, K., Hallstrom, K., Leustek, M., Parsosns, J., Abi-Akar, H.: Impact of Biodiesel Impurities on the Performance and Durability of DOC, DPF and SCR Technologies. SAE Int. J. Fuels Lubr. 4(1), 110-124 (2011)

[54] Lamharess, N.: Ph-D Thesis, University Pierre and Marie Curie, Paris, France (2012)

[55] Salamanca, M., Mondragón, F., Ramiro Agudelo, J., Benjumea, P., Santamaría, A.: Variations in the chemical composition and morphology of soot induced by the unsaturation degree of biodiesel and a biodiesel blend. Combust. Flame 159, 1100-1108 (2012)

[ 56] Vander Wal, R.L., Mueller, C.J.: Initial investigation of effects of fuel oxygenation on nanostructure of soot from a direct-injection diesel engine. Energy Fuels 20(6), 2364-2369 (2006)

[57] Christou, S.Y., Birgersson, H., Efstathiou, A.M.: Reactivation of severely aged commercial threeway catalysts by washing with weak EDTA and oxalic acid solutions. Appl. Catal. B Environ. 71, 185198 (2007)

[58] Othman, M.R., Mustafa, N.N.N., Ahmad, A.L.: Effect of thermal treatment on the microstructure of sol-gel derived porous alumina modified platinum. Microporous Mesoporous Mater. 91, 268-275 (2006) 
[59] Hauff, K., Tuttlies, U., Eigenberger, G., Nieken, U.: Platinum oxide formation and reduction during NO oxidation on a diesel oxidation catalyst - Experimental results. Appl. Catal. B Environ. 123-124, $107-116(2012)$

[60] Wang, D., Zhang, L., Li, J., Kamasamudram, K., Epling, W.S.: $\mathrm{NH}_{3}-\mathrm{SCR}$ over Cu/SAPO-34 Zeolite acidity and $\mathrm{Cu}$ structure changes as a function of $\mathrm{Cu}$ loading. Catal. Today 231, 64-74 (2014)

[61] Ma, L., Cheng, Y., Cavataio, G., McCabe, R.W., Fu, L., Li, J.: Characterization of commercial CuSSZ-13 and Cu-SAPO-34 catalysts with hydrothermal treatment for $\mathrm{NH}_{3}-\mathrm{SCR}$ of $\mathrm{NOx}$ in diesel exhaust. Chem. Eng. J. 225, 323-330 (2013).

[62] Kwak, J.H., Tonkyn, R.G., Kim, D.H., Szanyi, J., Peden, C.H.F.: Excellent activity and selectivity of Cu-SSZ-13 in the selective catalytic reduction of NOx with $\mathrm{NH}_{3}$. J. Catal. 275, 187-190 (2010).

[63] Kim, Y.J., Lee, J.K., Min, K.M., Hong, S.B., Nam, I.S., Cho, B.K.: Hydrothermal stability of CuSSZ13 for reducing $\mathrm{NOx}$ by $\mathrm{NH}_{3}$. J. Catal. 311, 447-457 (2014).

[64] Brandenberger, S., Kröcher, O., Tissler, A., Althoff, R.: The State of the Art in Selective Catalytic Reduction of NOx by Ammonia Using Metal-Exchanged Zeolite Catalysts. Catal. Rev. 50, 492-531 (2008).

[65] Metkar, P. S., Salazar, N., Muncrief, R., Balakotaiah, V., Harold, M. P.: Selective catalytic reduction of $\mathrm{NO}$ with $\mathrm{NH}_{3}$ on iron zeolite monolithic catalysts: Steady-state and transient kinetics. Appl. Catal. B 104, 110-126 (2011).

[66] Sjövall, H., Olsson L., Fridell, E., Blint, R. J.: Selective catalytic reduction of NOx with $\mathrm{NH}_{3}$ over Cu-ZSM-5-The effect of changing the gas composition. Appl. Catal. B 64, 180-188 (2006)

[67] Trombetta, M., Busca, G., Rossini, S., Piccoli, V., Cornaro, U., Guercio, A., Catani, R., Willey, R.J.: FT-IR Studies on Light Olefin Skeletal Isomerization Catalysis: III. Surface Acidity and Activity of Amorphous and Crystalline Catalysts Belonging to the $\mathrm{SiO}_{2}-\mathrm{Al}_{2} \mathrm{O}_{3}$ System. J. Catal. 179, 581-596 (1998)

[68] Wichterlová, B., Tvarůžková, Z., Sobalík, Z., Sarv, P.: Determination and properties of acid sites in H-ferrierite: A comparison of ferrierite and MFI structuresMicro. Meso. Mater. 24, 223-233 (1998)

[69] Leistner, K., Mihai, O., Wijayanti, K., Kumar, A., Kamasamudram, K., Currier, N.W., Yezerets, A., Olsson L.: Comparison of Cu/BEA, Cu/SSZ-13 and Cu/SAPO-34 for ammonia-SCR reactions. Catalysis Today 258, 49-55 (2015)

[70] Sepúlveda, C., Delgado, L., García, R., Melendrez, M., Fierro, J.L.G., Ghampson, I.T., Escalona, N.: Effect of phosphorus on the activity of $\mathrm{Cu} / \mathrm{SiO}_{2}$ catalysts in the hydrogenolysis of glycerol. Catalysis Today 279, 217-223 (2017)

[71] Mamontov, G.V., Magaev, O.V., Knyazev, A.S., Vodyankina, O.V.: Influence of phosphate addition on activity of $\mathrm{Ag}$ and $\mathrm{Cu}$ catalysts for partial oxidation of alcohols. Catalysis Today. 203, 122$126(2013)$

[72] Henriques, C., Ribeiro, M.F., Abreu, C., Murphy, D.M., Poignant, F., Saussey, J., Lavalley J.C.: An FT-IR study of NO adsorption over Cu-exchanged MFI catalysts: Effect of $\mathrm{Si} / \mathrm{Al}$ ratio, copper loading and catalyst pre-treatment. Applied Catalysis B 16, 79-95 (1998)

[ 73 ] Hadjiivanov, K.I.: Identification of Neutral and Charged NxOy Surface Species by IR Spectroscopy. Catalysis Reviews. 42, 71-144. (2000)

[74] De Ménorval, B., Ayrault, P., Gnep, N.S.,Guisnet, M.: Mechanism of n-butene skeletal isomerization over HFER zeolites: a new proposal. J. Catal. 230, 38-51 (2005)

[75] Lamharess, N., Millet, C.N., Starck, L., Jeudy, E., Lavy, J., Da Costa, P.: Catalysed diesel particulate filter: Study of the reactivity of soot arising from biodiesel combustion. Catal. Today 176, 219-224 (2011)

[76] Cosseron, A-F, Ph-D Thesis, University Haute Alsace, Mulhouse, France (2012)

[77] Song, J., Alam, M., Boehman, A.L., Kim, U.: Examination of the oxidation behavior of biodiesel soot. Combust. Flame 146(4), 589-604 (2006)

[78] Jung, H., Kittelson, D.B., Zachariah, M.R.: Characteristics of SME biodiesel-fueled diesel particle emissions and the kinetics of oxidation. Environ. Sci. Technol. 45 (24), 10337-10343 (20061) 
[79] Kashif, M., Bonnety, J., Guibert, P., Morin, C., Legros, G.: Soot volume fraction fields in unsteady axis-symmetric flames by continuous laser extinction technique. Opt Express. 20, 28742-28751 (2012). [80] Kashif, M., Guibert, P., Bonnety, J., Legros, G.: Sooting tendencies of primary reference fuels in atmospheric laminar diffusion flames burning into vitiated air. Combust Flame 161, 1575-1586 (2014) [81] Santoro, R.J., Semerjian, H.G., Dobbins, R.A.: Soot particle measurements in diffusion flames. Combust Flame. 51, 203-218 (1983).

[82] Abboud, J., Schobing, J., Legros, G., Bonnety, J., Tschamber, V., Brillard, A., Leyssens, G., Lauga, V., Iojoiu, E.E., Da Costa, P.: mpacts of oxygenated compounds concentration on sooting propensities and soot oxidative reactivity: Application to Diesel and Biodiesel surrogates. Fuel 193, 241-253 (2017). [83] Sadezky, A., Muckenhuber, H.,Grothe, H., Niessner, R., Pöschl, U.: Raman microspectroscopy of soot and related carbonaceous materials: Spectral analysis and structural information. Carbon 43, 1731$1742(2005)$

[84] Strzelec, A., Wal, R.L.V., Thompson, T.N., Toops, T.J., Daw, C.S.: NO2 Oxidation Reactivity and Burning Mode of Diesel Particulates. Top Catal 59, 686-694 (2016).

[85] Schobing, J., Tschamber, V., Brillard, A., Leyssens, G.: Impact of Biodiesel impurities on carbon oxidation in passive regeneration conditions: Influence of the alkali metals. Submitted.

[86] Stanmore, B.R., Tschamber,V., Brilhac, J.-F.: Oxidation of carbon by NOx, with particular reference to $\mathrm{NO}_{2}$ and $\mathrm{N}_{2} \mathrm{O}$. Fuel 87, 131-146 (2008)

[87] Matarrese, R., Castoldi, L., Lietti L.: Oxidation of model soot by $\mathrm{NO}_{2}$ and $\mathrm{O}_{2}$ in the presence of water vapor. Chem.Eng. Sci. 173, 560-569 (2017) 